\title{
Processes and deformation rates generating seismicity in metropolitan France and conterminous Western Europe
}

\author{
Stéphane Mazzotti ${ }^{1, *}$, Hervé Jomard ${ }^{2}$ and Frédéric Masson ${ }^{3}$ \\ ${ }^{1}$ Géosciences Montpellier, Université de Montpellier, CNRS, Université des Antilles, Montpellier, France \\ ${ }^{2}$ Bureau d'évaluation des risques sismiques pour la sûreté des installations, Institut de Radioprotection et Sûreté Nucléaire, \\ Fontenay-aux-Roses, France \\ ${ }^{3}$ Institut de Physique du Globe de Strasbourg, Ecole et Observatoire des Sciences de la Terre, CNRS, Université de Strasbourg, \\ Strasbourg, France
}

Received: 16 December 2019 / Accepted: 22 May 2020

\begin{abstract}
Most of metropolitan France and conterminous Western Europe is currently located within the Eurasia intraplate domain, far from major plate boundaries (the Atlantic ridge and Nubia-Eurasia convergence zone). As in other intraplate regions, present-day deformation and seismicity rates are very slow, resulting in limited data and strong uncertainties on the ongoing seismotectonics and seismic hazards. In the last two decades, new geological, seismological and geodetic data and research have brought to light unexpected deformation patterns in metropolitan France, such as orogen-normal extension $c a .0 .5 \mathrm{~mm} \mathrm{yr}^{-1}$ in the Pyrenees and Western Alps that cannot be associated with their mountain-building history. Elsewhere, present-day deformation and seismicity data provide a partial picture that points to mostly extensive to strike-slip deformation regimes (except in the Western Alps foreland). A review of the numerous studies and observations shows that plate tectonics (plate motion, mantle convection) are not the sole, nor likely the primary driver of present-day deformation and seismicity and that additional processes must be considered, such as topography potential energy, erosion or glacial isostatic adjustment since the last glaciation. The exact role of each process probably varies from one region to another and remains to be characterized. In addition, structural inheritance (crust or mantle weakening from past tectonic events) can play a strong role in deformation localization and amplification up to factors of 5-20, which could explain some of the spatial variability in seismicity. On the basis of this review, we identify three research directions that should be developed to better characterize the seismicity, deformation rates and related processes in metropolitan France: macroseismic and historical seismicity, especially regarding moment magnitude estimations; geodetic deformation, including in regions of low seismicity where the ratio of seismic to aseismic deformation remains a key unknown; an integrated and consistent seismotectonic framework comprising numerical models, geological, seismological and geodetic data. The latter has the potential for significant improvements in the characterization of seismicity and seismic hazard in metropolitan France but also Western Europe.
\end{abstract}

Keywords: seismicity / present-day deformation / seismotectonics / France / intraplate processes / seismic hazard

Résumé - Processus et taux de déformation générant la sismicité en France métropolitaine et en Europe occidentale proche. La majeure partie de la France métropolitaine et de l'Europe occidentale voisine est actuellement située dans le domaine intraplaque Eurasie, loin des principales limites de plaques (la dorsale atlantique et la zone de convergence Nubie-Eurasie). Comme dans les autres régions intraplaques, les taux de déformation et de sismicité actuels sont très lents, résultant dans de fortes limites et incertitudes sur la sismotectonique actuelle et les aléas sismiques. Au cours des deux dernières décennies, de nouvelles données et recherches géologiques, sismologiques et géodésiques ont mis en évidence des modes de déformation inattendus en France métropolitaine, comme l'extension ca. $0,5 \mathrm{~mm} \mathrm{a}^{-1}$ perpendiculaire à la chaîne dans les Pyrénées et les Alpes occidentales qui ne peut pas être associée à l'histoire de formation des montagnes. Ailleurs, les données actuelles sur la déformation et la sismicité fournissent une image partielle qui indique des régimes de déformation généralement en extension ou décrochement (sauf dans l'avant-pays

\footnotetext{
*Corresponding author: stephane.mazzotti@umontpellier.fr
} 
des Alpes occidentales). Une revue des nombreuses études et observations montre que la tectonique des plaques (mouvement des plaques, convection du manteau) n'est pas le seul, ni probablement le principal moteur de la déformation actuelle et de la sismicité, et que des processus supplémentaires doivent être envisagés, tels que l'énergie potentielle de la topographie, l'érosion ou le réajustement isostatique glaciaire depuis la dernière glaciation. Le rôle exact de chaque processus varie probablement d'une région à l'autre et reste à caractériser. De plus, l'héritage structural (affaiblissement de la croûte/du manteau à la suite d'événements tectoniques passés) peut jouer un rôle important dans la localisation et l'amplification de la déformation jusqu'à des facteurs de 5-20, ce qui pourrait expliquer une partie de la variabilité spatiale de la sismicité. Sur la base de cette revue, nous identifions trois axes de recherche qui devraient être développés pour mieux caractériser la sismicité, les taux de déformation et les processus associés en France métropolitaine : la sismicité macrosismique et historique, notamment en ce qui concerne les estimations des magnitudes de moment ; la déformation géodésique, y compris dans les régions de faible sismicité où le rapport de la déformation sismique à asismique reste un paramètre majeur inconnu; un cadre sismotectonique intégré et cohérent comprenant modèles numériques et données géologiques, sismologiques et géodésiques. Ce dernier a le potentiel pour des améliorations significatives dans la caractérisation de la sismicité et des aléas sismiques en France métropolitaine mais aussi en Europe occidentale.

Mots clés : sismicité / déformation actuelle / sismotectonique / France / processus intraplaque / aléa sismique

\section{Introduction}

From a plate tectonics perspective, most of metropolitan France and conterminous Western Europe presently belongs to the Eurasia plate (Fig. 1). Geological, seismological and geodetic data indicate that the $4-6 \mathrm{~mm} \mathrm{yr}^{-1}$ Nubia-Eurasia convergence is primarily accommodated along the Maghreb northern margin, with local complexities associated to microplates in southernmost Spain and around the Adriatic region (D’Agostino et al., 2008; DeMets et al., 2010; Nocquet, 2012). Thus, aside from the Western Alps, metropolitan France corresponds to first order to an intraplate domain, far from major plate boundaries (Fig. 1).

The question of the processes and forces responsible for intraplate seismicity is a major scientific conundrum. A variety of hypotheses are proposed, covering a large range of spatial and temporal scales, from fault intersections or crustal density contrasts acting as local stress concentrators, to plate-scale stress transfer from far-field boundaries, or stress reservoirs from past tectonic events (Sykes, 1978; Mazzotti, 2007; Calais et al., 2016; Talwani, 2016). Whereas the steady-state loading of plate tectonics generally dominates in plate boundary regions, its minor role in intraplate regions results in complex relationships between strain accumulation and earthquake strain release that depend on the driving mechanisms. This complexity leads to a spectrum of models for present-day intraplate deformation and seismicity that lie between two end members: on the one hand, dynamics of intraplate regions are considered similar to, but much slower than those of plate boundary zones, with slow loading rates and earthquakes recurring over long return periods; on the other hand, intraplate dynamics are considered different from those in plate boundary regions, with negligible loading rates and earthquakes that may not repeat over geological time scales (Calais et al., 2016). This lack of a consensual framework to explain intraplate deformation leads to significant uncertainties in the characterization of seismicity and associated seismic hazard (Stein and Mazzotti, 2007).

In the last two decades, a wealth of new geological, seismological and geodetic data has brought to light unexpected modes of deformation in metropolitan France, leading to the development of new models trying to identify the processes and mechanisms at the origin of the present-day deformation and seismicity. Most of these studies deal with a specific process applied to a specific region (Western Alps, Upper Rhine Graben, etc.). In this review article, we propose an overview and synthesis of these studies in order to put together and discuss the variety of information on deformation rates and processes at the origin of seismicity in France and conterminous Western Europe. Because of its scope and the sheer volume of related publications, this review does not provide an exhaustive overview of all studies associated with seismicity, present-day deformation or geodynamic processes. As such, most of the references used in this article are meant to be taken as "exempli gratia" (e.g.) and do not indicate that they are the sole or primary contributors to the related topic. Readers should refer to the original studies for additional references and information.

This review article is organized in four main sections. First, we present the current knowledge on seismicity in metropolitan France (Sect. 2) from the perspective of instrumental, historical and geological data. In the following section, we present the recent advances in the characterization of the kinematics and deformation rates using land and space geodesy (Sect. 3). Models of processes and mechanisms driving this deformation and seismicity are presented in Section 4. Finally, we discuss some of the implications for better characterizing the seismicity and seismic hazard estimations in France (Sect. 5).

\section{Seismicity}

Seismic networks record daily seismic activity in metropolitan France. Although most earthquakes are too weak to be felt by the population, some are felt every few weeks, produce minor damages every few years, or cause building collapses and deaths every few decades. Historical and geological studies show that similar or possibly larger, more damaging events have occurred in the past, indicating that, 


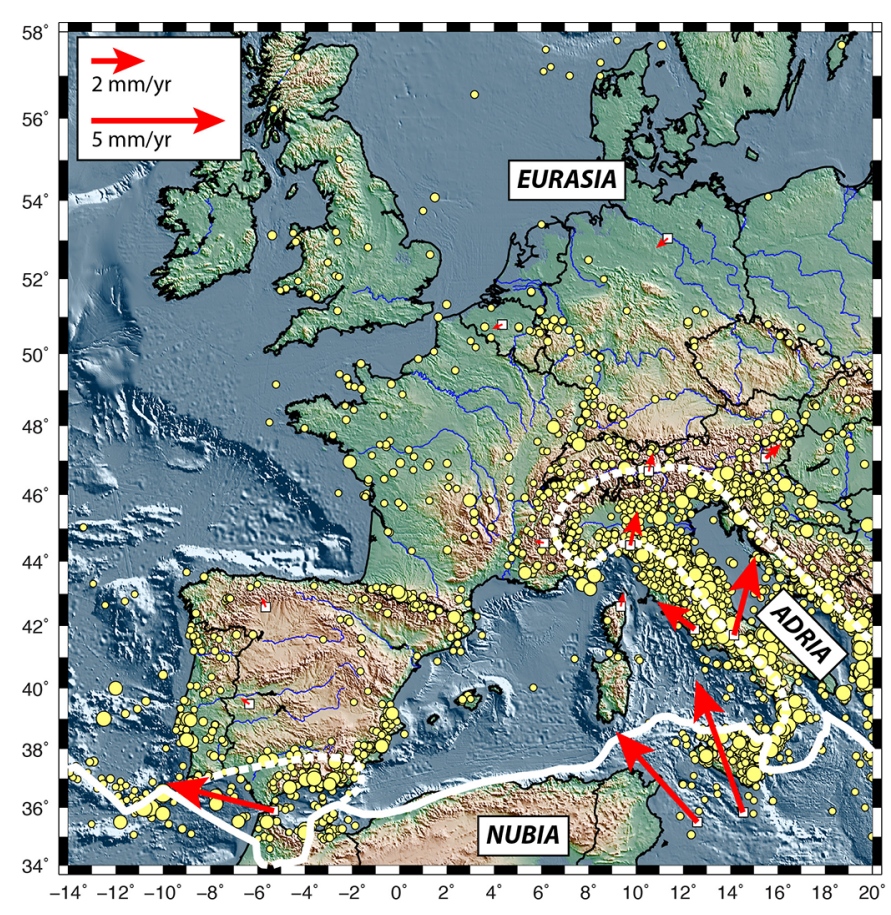

Fig. 1. Present-day tectonic setting of Western Europe. The solid white line shows the Nubia-Eurasia plate boundary. Dashed white lines show the boundaries of the Adria and Alboran micro-plates. Small (resp. large) yellow circles show earthquakes of magnitude $\mathrm{Mw} \geq 4.5$ (resp. $\mathrm{Mw} \geq 6.0$ ) from AD 1000 to 2006 (SHARE catalogue, Giardini et al., 2013). Red vectors with white bases show GNSS velocities relative to Western Europe (Masson et al., 2019b) for a few selected sites illustrating the relative plate and micro-plate motions.

although rare on the scale of a lifetime, destructive earthquakes cannot be ruled out.

Hereafter, earthquake magnitudes are given as a moment magnitudes $(\mathrm{Mw})$ when available or as a generic magnitudes (M) otherwise, without discriminating between the various types of local magnitude estimations (cf. Cara et al., 2015 for details on magnitude conversions).

\subsection{Pre-instrumental and instrumental seismicity}

The first seismological recording system in France is installed in 1892 in Strasbourg (then part of the Prussian Empire), followed in the next decades by additional observatories in Paris-St. Maur, Marseille, Puy de Dôme ... Because of their scarcity and limited sensitivity, their records do not provide the same level of information as modern networks and this period is thus often qualified as "preinstrumental". These observatories have recorded significant events, such as the deadly 1909 Lambesc earthquake (Baroux et al., 2003), and contributed to the release of the first instrumental catalogues on a relatively regular monthly to yearly basis during the first half of the 20th century. Along with similar records from other countries, these pre-instrumental records are now digitized and reanalyzed in order to infer the characteristics of early 1900s earthquakes (Lee et al., 1988; Cara et al., 2008; Amorèse et al., 2020).
Starting in the early 1960s, instrumental coverage in metropolitan France becomes generally sufficient to observe all earthquakes felt by the population (i.e., $\mathrm{M} \geq \sim 2.5$ ). From 1962 , a national network is deployed by the "Commissariat à l'Energie Atomique" (CEA), which contributes to the characterization of metropolitan seismicity by releasing yearly bulletins and catalogues, according to the CEA responsibility for seismic alerts to the French authorities. From the 1980s, several national and regional networks are developed for academic research and public communication purposes (e.g., RéNaSS, Sismalp). They are now integrated within the RESIF network (https://www.resif.fr), which will comprise $c a$. 300 stations covering the whole territory in 2020 .

SI-Hex (Cara et al., 2015) is the most recent and complete catalogue of instrumental earthquakes for metropolitan France and cross-border areas, covering 1962-2009. Figure 2 presents the SI-Hex catalogue and its most recent complement up to 2018. During this period, over 50000 earthquakes have been recorded with a completeness magnitude $\mathrm{Mw} \approx 2.5$. Owing to the network developments in the last five years, the annual number of recorded earthquakes has increased, reaching over 5000 in 2017 (Fig. 2b), albeit with a relative low ca. 2012-2015 due to network redeployments during the installation of the new broadband network (RLBP). The seismicity follows a classical Gutenberg-Richter distribution (i.e., earthquake frequencies inversely proportional to their magnitudes) with $c a$. 10 15 earthquakes of magnitude $\mathrm{Mw} \geq 3.0$ every year, and slightly less than one $\mathrm{Mw} \geq 4.0$ per year (Fig. 2c). The extrapolation of this distribution to large magnitudes would indicate a magnitude $\mathrm{Mw} \geq 6.0$ roughly every 300 years. This extrapolation is problematic in light of the historical data and long-term catalogue stability (cf. Sect. 2.4).

Apart from the Paris and Aquitaine Basins, the whole country is affected by moderate, diffuse seismicity (Fig. 2a). The most active areas are the Pyrenees and Alps mountains. In the former, seismicity covers the whole mountain range, with higher activity in the central and western regions, whereas earthquakes in the French Alps tend to concentrate along the internal (eastern) part of the range. A lower seismic activity extends to northeastern France (Jura, Alsace, Vosges), where earthquakes mainly concentrate in the Sundgau, north of the Jura front, the Rhine Graben and the Vosges Mountains. Sparser seismicity is recorded in central and western France, in the Armorican Massif and the Massif Central. By 2020, the densification of the seismological network should improve small earthquake $(\mathrm{M}<2)$ detections and could modify the details of this seismicity distribution, especially in low-density areas such as the Aquitaine and Paris Basins.

Medium to large ( $\mathrm{Mw}>4.5-5)$ instrumental earthquakes have been recorded in all regions with background seismicity (Fig. 2a). The most notable include:

- In the Pyrenees: Arette, August 13, 1967, Mw $=5.2$ (most recent deadly earthquake);

- In the Alps: Corrençon-en-Vercors, April 25, 1962, Mw= 5.5; Annecy, July 15, 1996, Mw =4.9; Barcelonnette, April 7, 2014, Mw = 4.8;

- Along the Ligurian margin: July 19, 1963, Mw =6.0; 

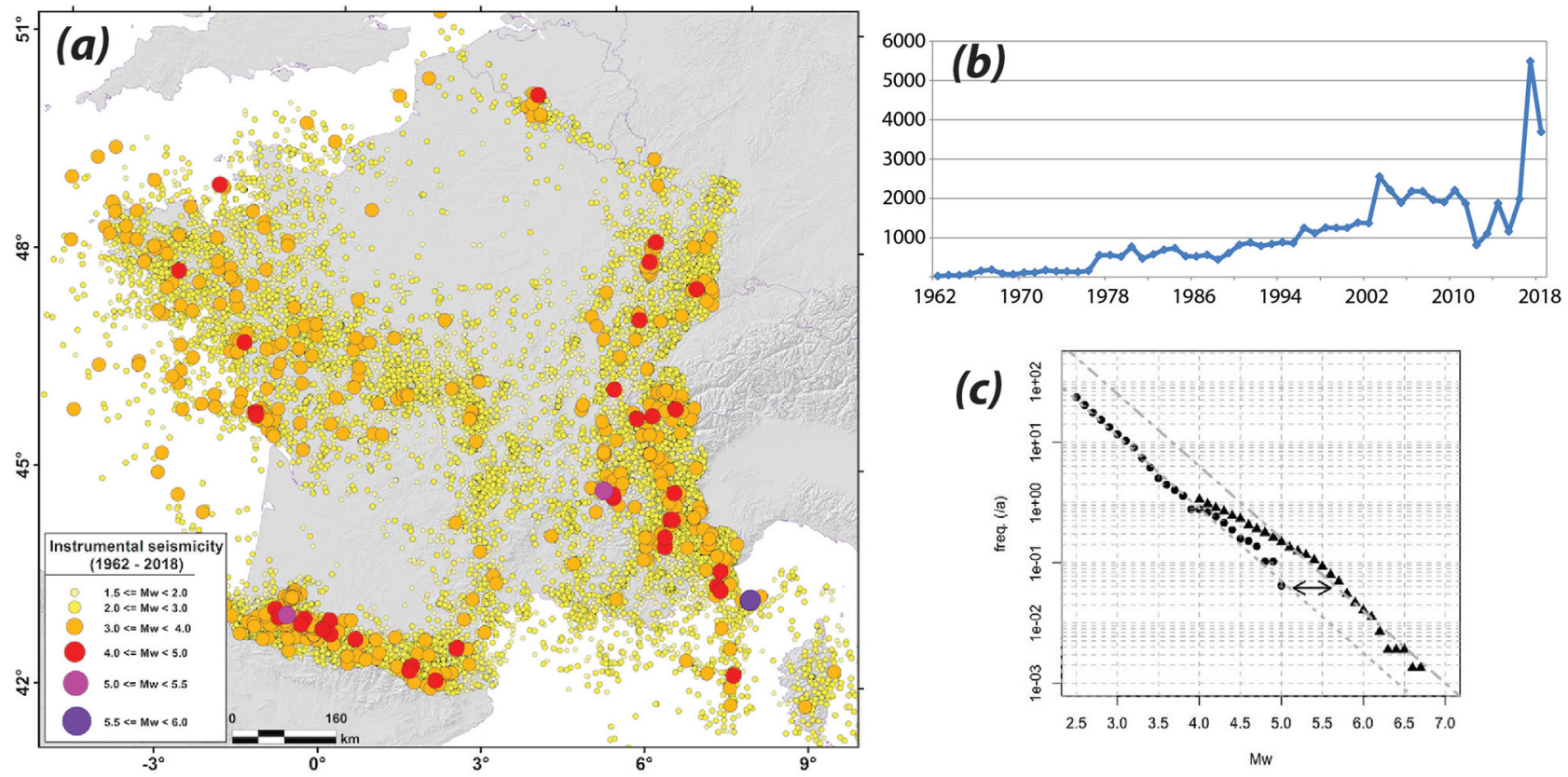

Fig. 2. Instrumental seismicity in metropolitan France. (a) Map of the extended SI-Hex catalogue (1962-2018). Colored circles indicate earthquake magnitudes Mw. (b) Number of recorded earthquakes per year. (c) Cumulative magnitude-frequency distribution of seismicity. Solid circles: Instrumental SI-Hex catalogue (1962-2018), Mw $\geq 2.5$. Solid triangles: historical \& instrumental FCAT17 catalogue (Manchuel et al., $2018)$, $M w \geq 4.0$. Dotted and dashed grey lines show best-fit Gutenberg-Richter models for each catalogue, with the double-head arrow indicating an apparent offset of 0.5 magnitude point.

- In Alsace and the Vosges: Rambervillers, February 22, 2003, Mw $=4.9$;

- In western France: Oléron, September 7, 1972, Mw=5.0. Most recently, the November 11, 2019 Le Teil earthquake (near Montélimar), $\mathrm{Mw}=4.9$, serves as a reminder that significant seismicity may also occur along the Rhone Valley.

Swarm seismicity is also recorded, characterized by series of earthquakes restricted to few kilometers and several weeks to months, with no clear mainshock/aftershock sequence. In recent years, one of the main swarm-prone areas is the upper Ubaye Valley (Alps), with more than 16000 earthquakes in 2003 and 2004, including several with magnitude $M>2$. Two earthquakes $\mathrm{M}>4$ with clear aftershock sequences occurred in February 2012 and April 2014 during the currently ongoing swarm (De Barros et al., 2019).

Focal mechanisms are also derived from instrumental seismicity, providing important information on faults and deformation. These data strongly depend on the network coverage and the velocity model used for the earthquake locations, especially for the small events $(M<3-4)$ that constitute the majority of data. Focal mechanism are estimated since the 1990s in numerous local- and national-scale studies, albeit with a strong emphasis on the Alps (Nicolas et al., 1990; Baroux et al., 2001; Mazabraud et al., 2005). A catalog of homogeneous and consistent mechanisms (computed with the same procedure) does not exist, but a national compilation, with first-order verification of the solutions and regional analyses, is produced within the RESIF framework (Mazzotti et al., subm.). This compilation, shown in Figure 3 for earthquakes of magnitude $\mathrm{Mw} \geq 4.0$, is developed as a guideline for seismotectonic studies of the metropolitan area, with limitations due to the heterogeneity of the original studies.

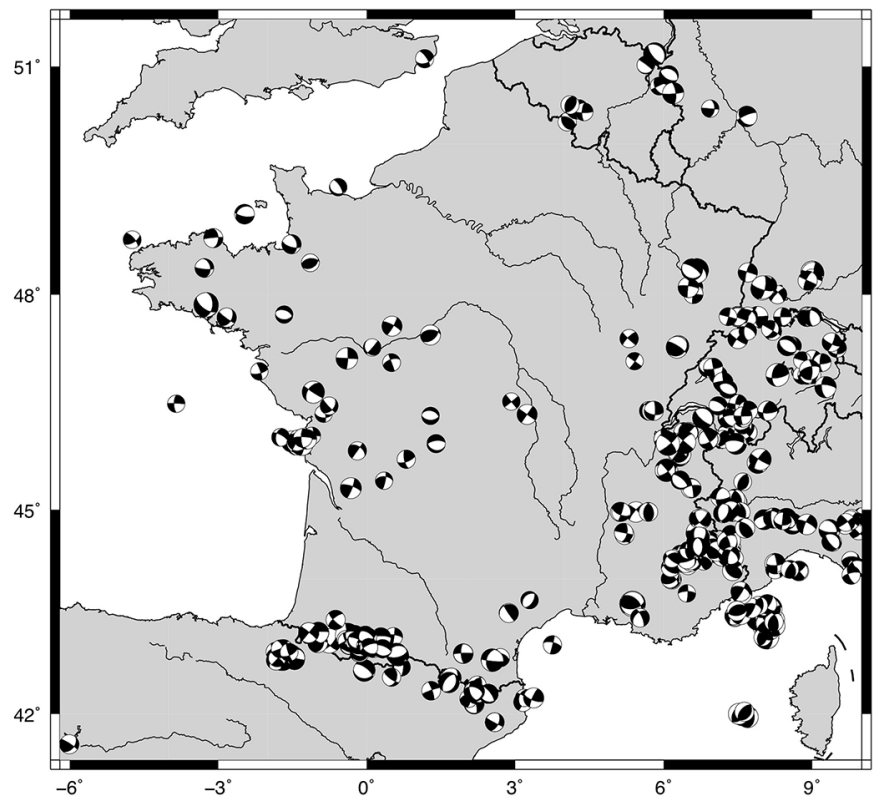

Fig. 3. Earthquake focal mechanisms in metropolitan France. Lower hemisphere projections of focal mechanisms for earthquakes of magnitude $\mathrm{Mw} \geq 4.0$ (compilation from Mazzotti et al., subm.).

\subsection{Macroseismic data and historical earthquakes}

Prior to the development of seismometers, earthquakes are mainly known from written records relating human testimonies and building damages from various sources (e.g., personal correspondences, parish or notarial acts, newspapers). 
(a)

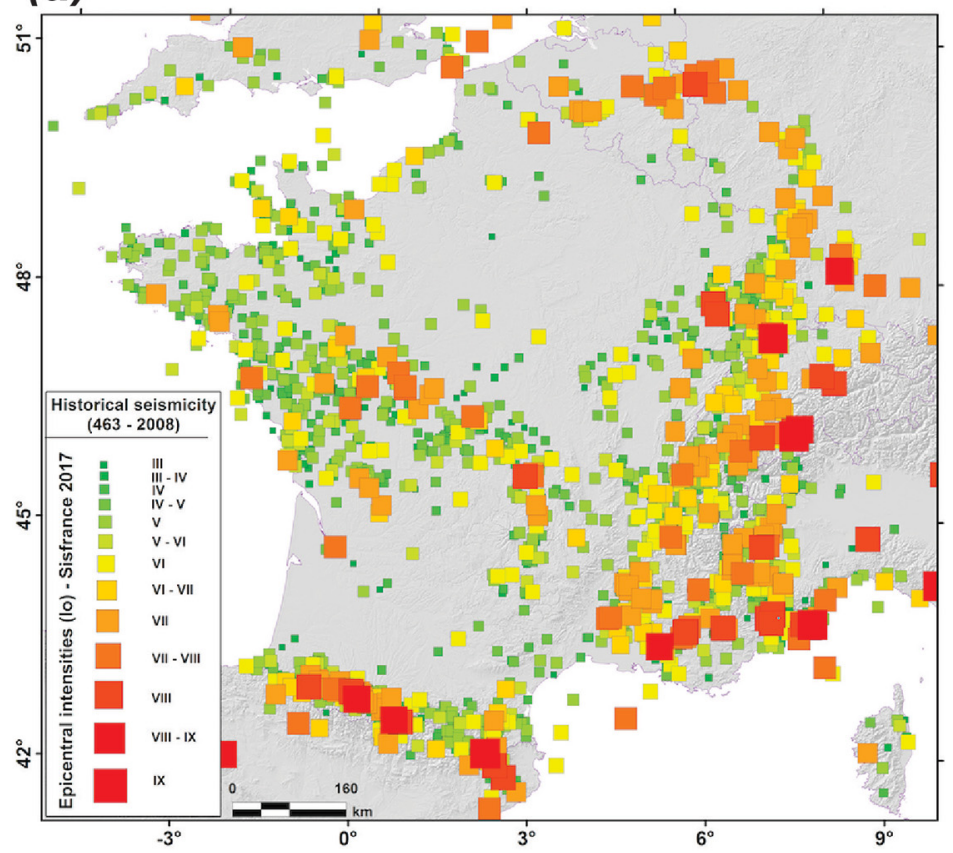

(b)

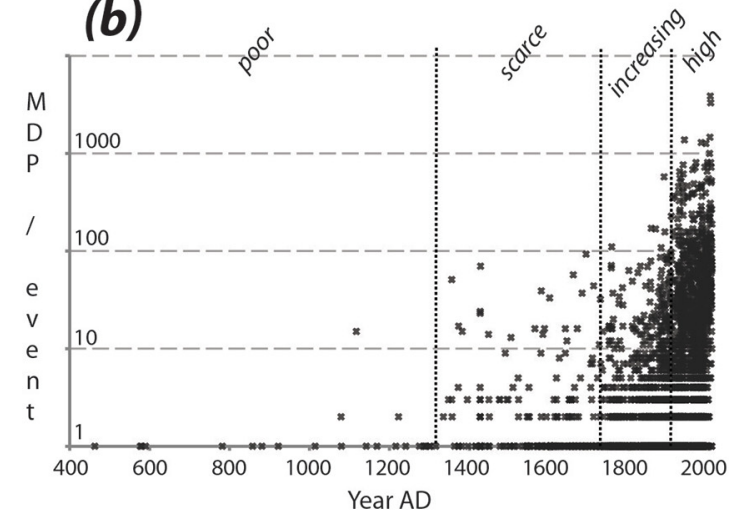

Fig. 4. Historical seismicity in metropolitan France. (a) Map of the 2017 SISFRANCE catalogue (AD 463-2008). Color squares indicate earthquake epicentral intensities $\mathrm{I}_{0}$. (b) Number of macroseismic data points (MPD) per event per year AD. "poor", "scarce", "increasing" and "high" indicate level of knowledge on historical earthquakes based on document types and availability.

Research on this subject starts at the end of the 18th century with the first national-scale catalog of historical seismicity (Perrey, 1845). Enrichment of this founding work leads to the SISFRANCE database (Scotti et al., 2004), in which testimony and damage records are interpreted relative to the MSK-64 intensity scale. Macroseismic surveys collecting testimony and damage information from municipalities are conducted in France since the 1909 Lambesc earthquake. They provide more exhaustive and rigorous information than those deduced from the analyses of archives, which depend strongly on historical document availability and interpretation. These surveys have become systematic after each felt earthquake post $c a$. 1920 with the creation of the "Bureau Central Sismologique Français" (BCSF, http://www.franceseisme.fr). This collection is not continuous through the 20th century but is complete since 1983, with macroseismic data defined nowadays on the EMS98 intensity scale.

The most recent release of the SISFRANCE historical earthquake catalog (2017), compiling macroseismic data from $217 \mathrm{BC}$ to $\mathrm{AD} 2008$, is presented in Figure 4. Earthquakes are associated with an epicentral intensity $\mathrm{I}_{0}(i$. $e$., intensity felt as close as possible to the estimated epicenter), providing a convenient way to separate felt earthquakes $\left(\mathrm{I}_{0}<\mathrm{VI}\right)$ from those that resulted in significant building damages $\left(\mathrm{I}_{0} \geq \mathrm{VI}\right)$. The latter represent about $5 \%$ of the historical earthquakes in metropolitan France (329 events over $c a .1500$ years). Epicentral intensities are estimated for 3114 events (post AD 463) over the 6390 in the database, in other words $c a .50 \%$ of the earthquakes that are documented cannot be associated with an epicenter location and intensity. The temporal evolution of the number of available macroseismic data points per event provides a general overview of the knowledge completeness we may expect from this database (Fig. 4b).

The general pattern of historical seismicity is consistent with the instrumental one (Figs. 4a vs. 2a), with some local complexities such as the Pas-de-Calais region where three large historical earthquakes have affected an area of very low instrumental activity (1382, $\mathrm{I}_{0}=\mathrm{VII}-\mathrm{VIII} ; 1449, \mathrm{I}_{0}=\mathrm{VII}$; $1580, \mathrm{I}_{0}=$ VII-VIII). A similar situation exists in Provence, where the instrumental seismicity near the Middle DuranceTrevaresse fault system is low in comparison with the historical events that occurred in the area $\left(1708, \mathrm{I}_{0}=\mathrm{VIII}\right.$; 1909, $\mathrm{I}_{0}=$ VIII-IX). These observations illustrate that while large earthquakes tend to occur in areas where background seismicity is important, it is not possible to exclude their occurrence in areas showing a low instrumental seismicity.

In addition to standard macroseismic studies, archeoseismology deals with the analysis of traces left by earthquakes on historical buildings and structures. It is not restricted to ancient times and can be applied to recent earthquakes, such as the 1708 Manosque earthquake (Quenet et al., 2004; Poursoulis and Levret-Albaret, 2014). For older events, very few data exist in France. For example, a study on the Nîmes Roman aqueduct concludes on the possible occurrence of one or two earthquakes causing disorders between AD 250 and 350 (Volant et al., 2008); archeological observations on Roman buildings in Vienne confirm the occurrence of a 5 th century event reported in the SISFRANCE database, with possibly older ones (Adjadj et al., 2014).

\subsection{Paleoseismicity and seismogenic faults}

Paleoseismology deals with direct and indirect effects left by earthquakes in the geological environment. Geological and 


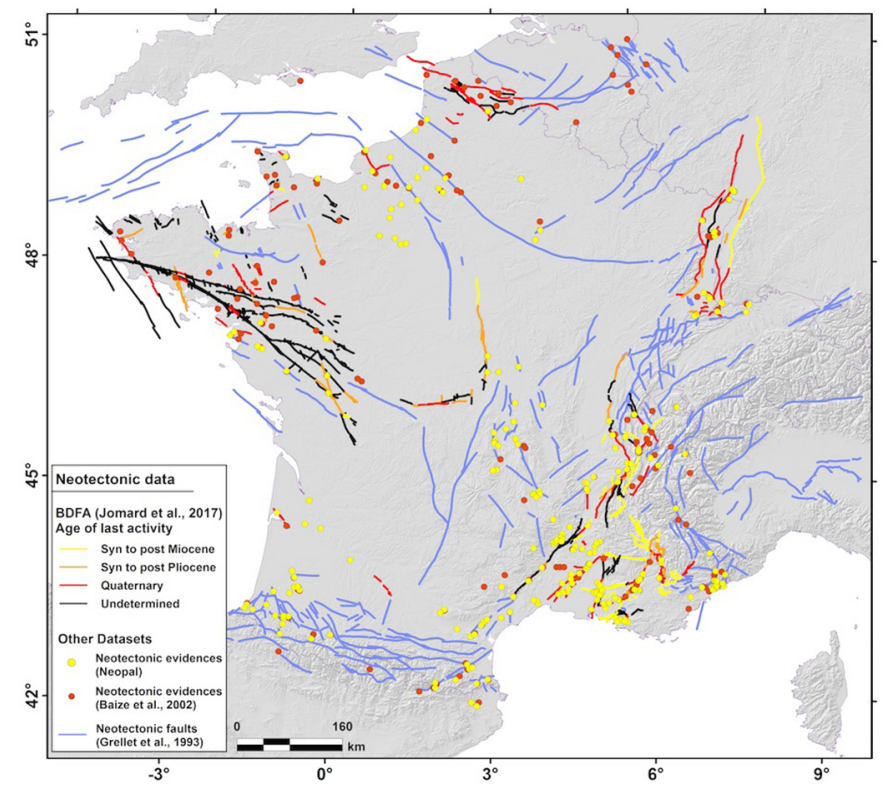

Fig. 5. Neotectonic data and potential seismogenic faults in metropolitan France. Light blue lines show tectonic faults from Grellet et al. (1993). Yellow and red circles show indications of post Miocene deformation from the NEOPAL database and from Baize et al. (2013). Black, red, orange and yellow lines show faults from the BDFA database of undetermined, Quaternary, syn/post Pliocene and syn/post Miocene age (Jomard et al., 2017).

geophysical observations can provide information on past earthquakes and seismogenic faults (i.e., faults that have generated or can generate earthquakes). The latter are particularly challenging to evaluate in intraplate domains, where field evidence is often tenuous and complex. In metropolitan France, few geological evidence exist of earthquake occurrence on identified faults, whereas numerous evidence of post-Miocene deformation point to significant uncertainties regarding possible unknown seismogenic faults.

The NEOPAL database provides a review of these data by a national expert committee (Fig. 5). Several compilations also exist on regional and national scales for potential neotectonic indices (Baize et al., 2013) and seismogenic faults (Grellet et al., 1993; Lacan and Ortuño, 2012). (Jomard et al., 2017) compile the most recent database of potential seismogenic faults within $50 \mathrm{~km}$ of nuclear facilities (BDFA, Fig. 5). Due to the lack or scarcity of constraints from Plio-Quaternary deformation, faults showing evidence of Miocene or younger deformation are considered as potentially seismogenic, assuming that the regional stress field has not experienced dramatic changes since then ( $c f$. Sect. 4.1 for discussion of this hypothesis). This approach is similar to the methodological framework proposed in recent reports to identify potential seismogenic faults in slow deforming regions (Bertil and Terrier, 2017; Terrier et al., 2018).

A major limitation of neotectonic and paleoseismic studies is their tendency to focus in regions of strong seismic activity, near major historical earthquakes or close to critical facilities (Sébrier et al., 1997; Ferry et al., 2005; de La Taille et al., 2015). As a result, most faults in regions of moderate seismicity have not been studied in terms of seismogenic potential (especially in the Massif Central, Brittany or most of the Rhône Valley) and the majority of identified potential seismogenic faults are located in Provence, the northern Alps, the Upper Rhine Graben and, to a lesser extent, the Pyrenees and southeastern Alps (Fig. 5).

Geological estimations of the magnitude and frequency of past and potential future earthquakes are also subject to debate. Scaling relationships relating fault offsets or dimensions are used to provide estimations of the associated magnitudes (Wells and Coppersmith, 1994), leading to geological-based magnitudes between $\mathrm{M} \approx 6$ and $\mathrm{M} \approx 7$ (Chardon et al., 2005; Ferry et al., 2005; Cushing et al., 2008). Very few faults are associated with direct observations of recurring earthquakes and their return periods: the Trevaresse Fault (Chardon et al., 2005) and the Bâle Reinach Fault (Ferry et al., 2005), plus potentially the Courthézon Fault (Combes et al., 1993). Fault slip rates can also be used to provide indirect estimations of earthquake return periods, but they are extremely difficult to constrain due to slow deformation rates, erosion and anthropic activities that limit the observations. In this context, few fault slip rates are determined in France and most correspond to Pleistocene to Miocene markers (Jomard et al., 2017).

New methods in archeoseismology and paleoseismology can provide important information to improve our understanding of seismicity. Archeoseismology has been developed mainly through qualitative observations (Quenet et al., 2004; Poursoulis and Levret-Albaret, 2014), with few quantitative studies (e.g., Nîmes aqueduct, (Volant et al., 2008)). Recent developments in seismic monitoring and numerical modeling of building response to shaking allow refined analyses of historical buildings and the level of shaking they experienced (c.f. study of medieval churches in Savoie (Limoge-Schraen et al., 2014)). Such quantitative approaches should provide new data on known or unknown historical earthquakes using the large stock of historical buildings in France. Similarly, substantial advances can be expected in paleoseismology. New surface and subsurface imaging and dating methods have been applied widely in numerous active tectonic regions, but as yet rarely in metropolitan France. LIDAR (Light Detection And Ranging) provides dramatic increases in the identification of geomorphic structures and active faults, including in intraplate regions (Mikko et al., 2015), but its accessibility remains limited for tectonic studies in France. Similarly, fault gouge dating of basement fault (Vrolijk et al., 2018) or studies of lacustrine deposits (Strasser et al., 2006; Beck, 2009) may dramatically improve the earthquake catalogs and address issues such as irregular seismic cycles or non-repeating earthquakes (Clark et al., 2012; Calais et al., 2016).

\subsection{Temporal variations of seismicity}

Temporal variations of seismicity can be studied by combining historical and instrumental data in a homogeneous seismicity catalogue, with a major difficulty due to the impact of regional seismic attenuation on magnitude estimations (Mayor et al., 2018). For the SI-Hex instrumental catalogue, this effect is accounted for by dividing the French territory into four attenuation regions (Cara et al., 2017). For historical earthquakes, the complex process of magnitude estimations from macroseismic data requires calibration events with instrumental $\mathrm{Mw}$ magnitudes, robust macroseismic fields and 

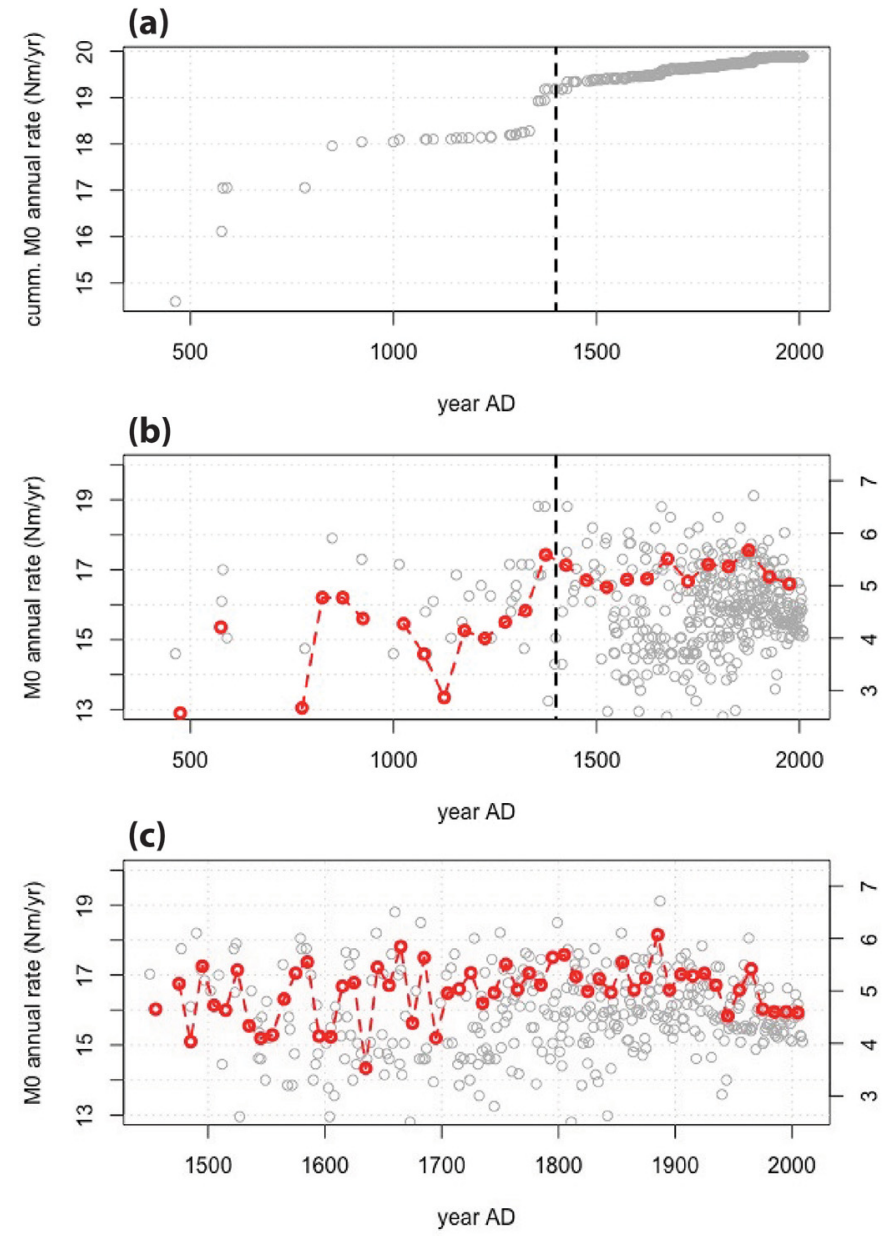

Fig. 6. Variations of annual seismic moment rates. Decimal logarithm of the cumulative (a) and incremental (b) annual rate of seismic moment from the FCAT-17 catalogue AD 400-2010. The red symbols in (b) show 50-year average. (c) Decimal logarithm of the incremental rate of seismic moment AD 1450-2010. The red symbols show 10year average. The right-end side labels show the equivalent $\mathrm{Mw}$ magnitude.

regional intensity attenuation laws (Bakun and Scotti, 2006; Baumont et al., 2018; Provost and Scotti, 2020). In France, the FCAT-17 catalogue (Manchuel et al., 2018) provides the most recent Mw estimations combining the instrumental SI-Hex and historical SISFRANCE datasets, taking into account available regional attenuation models.

The temporal evolution of annual seismic moment rate for AD 400-2010 based on FCAT-17 (excluding events labeled as "POOR" and with the addition of the July 19, 1963, Mw $=6.0$ Liguria earthquake) is shown in Figure 6. To a first order, two main periods are observed:

- Prior to the 15 th century, the annual moment rate shows strong variations due to the incompleteness of the catalog. Most events are associated with one intensity data point (Fig. 4b) with no mention of damage and magnitudes that are likely underestimated;

- Since to the 15 th century, the 50 -yr smoothed moment rate is stable $c a .10^{17} \mathrm{~N} \mathrm{~m} \mathrm{yr}^{-1}$, despite the constant increase in the numbers of macroseismic data (Fig. 4b), suggesting that most large earthquakes are known during this period and that a 50 -yr window allows smoothing out the few potential missing events.

The post-1450 period is shown in more details in Figure 6c. Smoothed over a 10 -year window, the annual seismic moment rate varies by $2-3$ orders of magnitude until $c a$. AD 1700 , after which it stabilizes to $c a .1 .1 \times 10^{17} \mathrm{~N} \mathrm{~m} \mathrm{yr}^{-1}$, suggesting that large earthquakes $(\mathrm{Mw} \geq 5)$ are likely complete for the whole post-1450 period, whereas some smaller $(\mathrm{Mw}<5)$ events should be missing pre-1700. During the 50 years of the post1960 instrumental period, the 10 -yr-averaged annual rate shows a systematic low $\left(\right.$ ca. $\left.0.1 \times 10^{17} \mathrm{~N} \mathrm{~m} \mathrm{yr}^{-1}\right)$ compared to the pre-1960 average. Three hypotheses may explain this apparent low activity of the post-1963 period:

- a systematic overestimation of the historical earthquakes (equivalent to 0.5 magnitude point) either from overestimations of intensities or from biases in the $\mathrm{Mw}$ magnitude estimations;

- a systematic underestimation (also equivalent to $0.5 \mathrm{mag}$ nitude point) of Mw magnitudes in SI-Hex;

- a $c a$. 50-year period of seismic quiescence since about 1960 , which has not been observed in the last 500 years.

A similar observation is made when comparing the magnitude-frequency distributions of the historical and instrumental catalogues (Fig. 2c). A systematic offset of $c a$. 0.5 magnitude point is evidenced between the two catalogues in the $\mathrm{Mw}=4.5-5.0$ range and for extrapolations of Gutenberg-Richter distributions. At present, no evidence allows rejecting any of the possible explanations, precluding a clear conclusion concerning temporal variations of seismicity and the associated seismic hazard in metropolitan France. Although new networks will provide important data for better characterization of the background seismicity, improvements to the historical earthquake catalogue and conversions to $\mathrm{Mw}$ magnitudes clearly stand out as a major requirement for future studies.

\section{Kinematics and deformation rates}

By definition, the primary characteristic of an intraplate region is its very low rate of deformation that cannot be quantified using classical geological data. Thus, geodetic data have been used to try and provide quantitative estimations of local and regional kinematics and strain rates in metropolitan France, initially using traditional land geodesy (triangulation, leveling) rapidly followed by space geodesy. The first publications using land geodetic surveys to study deformation in France followed closely the development of these techniques in plate-boundary regions such as California.

\subsection{Leveling and triangulation}

Due to its relatively low precision over long distances, land geodesy (leveling, triangulation, trilateration) requires surveys separated by several decades in order to estimate velocities with a precision level of a few $\mathrm{mm}^{-1}$ (i.e., a few $\mathrm{cm}$ over 
$10 \mathrm{yr})$. Early studies of vertical deformation combine the two major national leveling surveys (1887-1907 and 1965-1979) with additional regional surveys to derive relative rates of uplift and subsidence in various regions of France (Fourniguet, 1980). They typically estimate differential vertical velocities (uplift and subsidence) up to $1-3 \mathrm{~mm} \mathrm{yr}^{-1}$ over distances of $10-100 \mathrm{~km}$. These vertical motion are tentatively associated with active geological structures and faults, e.g., in Brittany (Lenôtre et al., 1999) or the Jura Mountains (Jouanne et al., 1995), although the results are at the limit of resolution of the leveling method, especially in regions of strong relief (Rigo and Cushing, 1999).

In contrast with leveling, only a few studies have considered triangulation and trilateration data for horizontal deformation analyses in France and neighboring regions (Reilly and Gubler, 1990; Jouanne et al., 1994). For example, the comparison of triangulation surveys in 1930-1936 and 1979-1984 suggests a shortening at rates up to $5 \mathrm{~mm} \mathrm{yr}^{-1}$ in the northern French Alps (Jouanne et al., 1994). Although compatible to first order with the limited deformation indicators (focal mechanisms) in this region, such a fast relative motion is likely an expression of the limited resolution of land geodesy data.

\subsection{Space geodesy, GPS, GNSS}

The advent of space geodesy, and in particular of GPS (Global Positioning System), strongly improved the precision of measurements of relative positions and displacements over distances of $10-1000 \mathrm{~km}$. Early GPS projects focus on resurveys of existing land geodesy networks in regions of expected fast deformation such as the Western Alps (Martinod et al., 1996; Ferhat et al., 1998; Calais et al., 2000b). These studies combine early triangulation data (typically from 19401950) with new GPS data (early 1990s) to estimate horizontal strain rates and relative velocities. The derived patterns of deformation indicate roughly $1-5 \mathrm{~mm} \mathrm{yr}^{-1}$ of NW-SE to N-S shortening from the northern to southern French Alps. The relatively low precision of the land geodesy data combined with the complexity of adjusting land geodesy and GPS measurements result in limited resolution and commonly overestimated deformation rates.

Specific GPS networks dedicated to geodynamics applications were installed in the mid to late 1990s, both in campaign (episodic) and permanent (continuous) acquisition modes, first in the Western Alps and slowly in other regions (Calais et al., 2000a; Vigny et al., 2002; Masson et al., 2010; The RENAG Team, 2010; Rigo et al., 2015). These geodetic networks are now complemented by large privately-operated networks installed during the 2000s for geomatics and cadaster applications, providing over 700 GNSS (Global Navigation Satellite System) stations in the metropolitan territory (Fig. 7). In parallel with network developments, the precision of geodetic velocity estimation has significantly improved in the last decade owing to the natural increase in time series duration and to improvements of GNSS characteristics, such as reference frame definition, satellite ephemerids or antenna calibrations (Dow et al., 2009). Analyses of noise and variability in GNSS data indicate that stations with $c a$. 10 years or more of measurements can currently provide estimations of

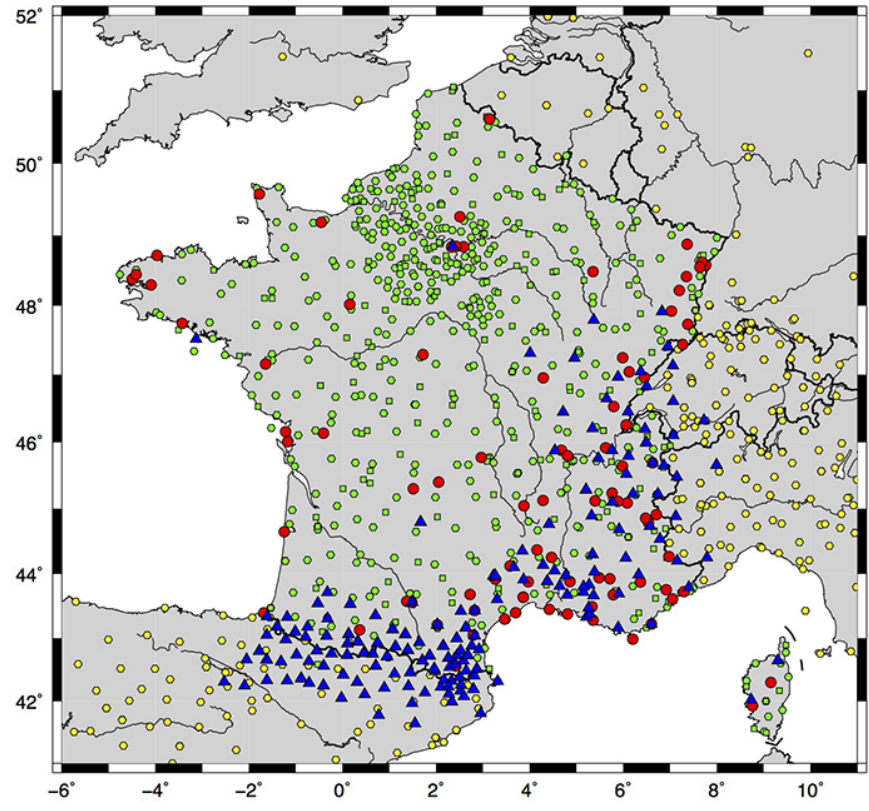

Fig. 7. GNSS networks in metropolitan France. Red circles show permanent RENAG and IGN stations. Green (resp. yellow) circles show permanent stations from other public and private operators in France (resp. in other countries). Blue triangles show campaign stations in the Pyrenees - Alps corridor.

horizontal (resp. vertical) velocities with a precision $c a$. $0.2 \mathrm{~mm} \mathrm{yr}^{-1}$ (resp. $0.5 \mathrm{~mm} \mathrm{yr}^{-1}$ ) at the $95 \%$ confidence level (Williams, 2003; Santamaría-Gómez et al., 2011; Masson et al., 2019a).

Owing to these concurrent network and technical developments, recent studies of regional GNSS velocities and strain rates have identified coherent and significant signals in the Western and Central Alps, the Pyrenees, and the Upper Rhine Graben. They are reviewed in the following sections. Outside of these regions, the majority of studies only provide approximate bounds on the maximum possible deformation equivalent to differential horizontal velocities of $0.2-0.5 \mathrm{~mm}$ $\mathrm{yr}^{-1}$ (Nocquet, 2012; Nguyen et al., 2016). However, very recent studies using network-based filtering technics indicate that coherent horizontal velocities can be resolved with a precision of $0.1-0.2 \mathrm{~mm} \mathrm{yr}^{-1}$ on spatial scales of $100-200 \mathrm{~km}$ (Masson et al., 2019b), resulting in the identification of complex deformation patterns in the whole metropolitan France that will require further analyses before they can be used in seismotectonic models.

\subsection{Western and Central Alps}

The most significant deformation observed in the Western and Central Alps is a present-day uplift rate up to $2-3 \mathrm{~mm} \mathrm{yr}^{-1}$ (Brockmann et al., 2012; Serpelloni et al., 2013; Nocquet et al., 2016). The density of geodetic stations, combined with the joint reevaluation of leveling data, allows a good determination of the spatial distribution of vertical motions (Fig. 8): uplift rates of $1.0-2.5 \mathrm{~mm} \mathrm{yr}^{-1}$ are limited to the Central Alps and the northern Western Alps, whereas the surrounding regions, including the southern Western Alps, do 
not show coherent significant vertical motion $(0.0 \pm 0.5 \mathrm{~mm}$ $\left.\mathrm{yr}^{-1}\right)$. At present, a more precise determination of the pattern of vertical motions is limited both by individual data quality and by data integration across the national borders.

Estimations of horizontal deformation also benefit from the recent GNSS data improvements, providing the first significant quantifications of present-day deformation in the Alps. In the Western Alps, the overall relative motion across the entire range, from the Po Plain to the Rhone Valley, is likely smaller than ca. $0.2 \mathrm{~mm} \mathrm{yr}^{-1}$ (Nocquet, 2012; Sánchez et al., 2018; Masson et al., 2019b). However, significant orogen-normal extension is observed in the inner alpine domains (Fig. 8) with strain rates ca. $(5-15) \times 10^{-9} \mathrm{yr}^{-1}$, equivalent to $0.5-1.5 \mathrm{~mm} \mathrm{yr}^{-1}$ over distances of $100 \mathrm{~km}$. This inner extension is combined with slower orogen-normal shortening rates ca. $(1-5) \times 10^{-9} \mathrm{yr}^{-1}$ in the French foreland (Sánchez et al., 2018; Walpersdorf et al., 2018; Masson et al., 2019b). These new geodetic-based deformation patterns are consistent with the seismicity and seismo-tectonic deformation indicators (Sue et al., 1999; Walpersdorf et al., 2015). The increase in the volume and precision of geodetic and seismicity data begs for a reassessment of the geodetic/seismicity comparison to address questions such as potential aseismic deformation (Sue et al., 2007).

These horizontal deformation patterns in the Western Alps are likely unrelated to the regional kinematics of the Adria micro-plate (Fig. 1). Rigid-block analyses define a counterclockwise rotation of Adria relative to Eurasia with a pole located in northwestern Italy, resulting in roughly N-S shortening the Eastern Alps and very small $\left(<0.5 \mathrm{~mm} \mathrm{yr}^{-1}\right)$ transtensive relative motions in the Western Alps (D'Agostino et al., 2008). In contrast, GPS data suggest a rapid transition from E-W extension in the French Western Alps to N-S extension near the French-Italy-Swiss border (Fig. 8), incompatible with the Adria micro-plate rotation and requiring additional driving mechanisms such as isostatic rebound from erosion, deglaciation from the Last Glacial Maximum, or European slab tear ( $c f$. Sect. 4).

\subsection{Pyrenees}

Recent campaign and permanent GPS data indicate a significant N-S extension rate across the Pyrenees Mountains ca. $(1-4) \times 10^{-9} \mathrm{yr}^{-1}$, equivalent to $c a .0 .1-0.4 \mathrm{~mm} \mathrm{yr}^{-1}$ over the whole $50-100 \mathrm{~km}$ width of the orogen (Asensio et al., 2012; Rigo et al., 2015; Masson et al., 2019b). The station density and data quality does not allow a more precise determination of the deformation localization, aside from suggestions of a smaller extension rates in the eastern Pyrenees compared to the western side (Fig. 8). As in the Western Alps, the orogen-normal extension is consistent in style with seismicity and neotectonic indicators (Fig. 3); in addition geodetic and seismic strain rates are in agreement within their uncertainties (Rigo et al., 2015). However, in contrast with the Western Alps, associated shortening of the Pyrenees foreland is presently not observed in geodetic data.

The low density of permanent GPS stations in the central part of the Pyrenees, as well as the low resolution of campaign data, put strong limits on the detection of significant vertical motion. Current data suggest no significant uplift or subsidence within $c a . \pm 0.5 \mathrm{~mm} \mathrm{yr}^{-1}$ in the inner domains and the forelands (Masson et al., 2019b).

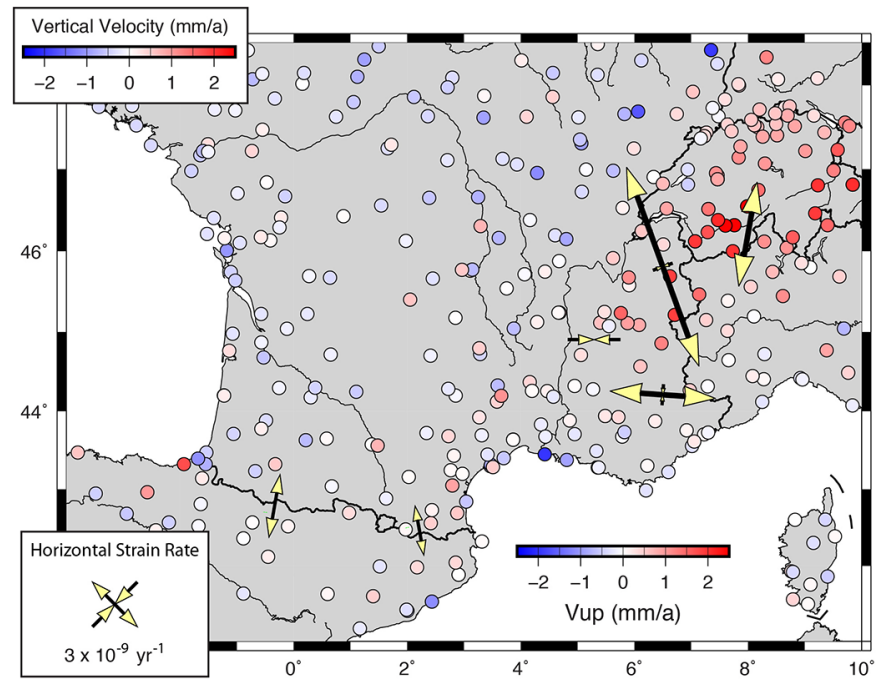

Fig. 8. GNSS vertical velocities and horizontal strain rates in the Alps and Pyrenees. Colored circles show vertical velocities at GNSS sites (for standard errors smaller $0.25 \mathrm{~mm} \mathrm{yr}^{-1}$; Masson et al., 2019b). Yellow and black crosses show horizontal strain rates in the Alps and Pyrenees ( $c f$. text for references).

As in the Alps, the relationship between these deformation patterns and the kinematics of a potentially independent Iberia micro-plate remains unclear. GPS data in Spain and Portugal suggest a clockwise rotation the Iberia micro-plate, relative to Eurasia, with a pole located in northern Spain southwest of the Pyrenees (Palano et al., 2015). The compatibility of this rigid rotation of an Iberia micro-plate with the strain rate estimations in the Pyrenees remains to be studied in detail.

\subsection{Upper Rhine Graben}

Tectonic deformation in the Upper Rhine Graben has so far been elusive. Studies using GNSS in combination with leveling or InSAR (Interferometry of Synthetic Aperture Radar) detect no significant horizontal deformation within ca. $\pm 0.3-0.5 \mathrm{~mm} \mathrm{yr}^{-1}$ of precision (Fuhrmann et al., 2015; Henrion et al., 2015). Alternatively, the most recent studies based on GNSS data alone suggest a general N-S shortening in the Vosges-Black Forest-Swiss Jura region $c a .1 \times 10^{-9} \mathrm{yr}^{-1}$ (eq. $0.1-0.2 \mathrm{~mm} \mathrm{yr}^{-1}$ ), which requires further analyses to compare with other neotectonic indicators (Sánchez et al., 2018; Masson et al., 2019b). Subsidence rates up to $0.5 \mathrm{~mm} \mathrm{yr}^{-1}$ are observed in the northern part of the Upper Rhine Graben over areas of 10-20 km dimension (Fuhrmann et al., 2015). Whether such subsidence signals can be of anthropic origin, especially in association with geothermal production, is the subject of ongoing research using various geodetic techniques, including gravimetry (Heimlich et al., 2015; Ferhat et al., 2017).

\section{Processes and models}

A variety of mechanisms and processes have been proposed to explain the deformation and seismicity in France, in general with application to a specific region. They can be 
classified in two main categories depending on whether they generate steady state or transient loading on a geological time scale ( $c a$. 1 Myr). The formers are associated with classical tectonic drivers such as plate kinematics, mantle convection or topography. The latter correspond to processes that have been proposed more recently and whose impact remains debated, such as erosion or glacial isostatic adjustment.

\subsection{Regional stress field and plate tectonics}

Since the 1980s, the World Stress Map project has resulted in a dramatic increase in the understanding of the state of stress in the crust and lithosphere (Zoback et al., 1989; Heidbach et al., 2018). In particular, numerous studies have shown that the orientations of the maximum horizontal compressive stress $\left(\sigma_{\mathrm{H}}\right)$ demonstrate a first-order spatial coherence at the continental scale that can be attributed to the effect of plateboundary forces (Zoback, 1992). In most of France and conterminous Western Europe, $\sigma_{\mathrm{H}}$ shows a general NW-SE to NNW-SSE orientation (azimuth $c a$. N 135-160', Fig. 9). Mechanical models show that this stress pattern is mainly due to the ridge-push force of the Mid-Atlantic Ridge combined with the subduction/collision resistance along the NubiaEurasia and Adria-Eurasia boundaries (Müller et al., 1992; Gölke and Coblentz, 1996).

This continental-scale NW-SE to NNW-SSE orientation of the maximum horizontal compressive stress is consistent with the local stress tensors derived from focal mechanism inversions in most of France and neighboring regions (Fig. 9). Strike-slip and extensional stress regimes associated with a NW-SE orientation of $\sigma_{\mathrm{H}}$ are observed in most of Brittany, Vendée and northern Massif Central (Delouis et al., 1993; Mazabraud et al., 2005), in the Lower Rhine Embayment and Rhenish Massif (Hinzen, 2003), and further south in the Upper Rhine Graben and Swiss Alpine foreland (Delouis et al., 1993). The Pyrenees show a similar combination of strike-slip and extensional regimes, but with stronger variations in the orientations of $\sigma_{\mathrm{H}}$ within the NW-SE quadrant (Rigo et al., 2015).

In contrast, the Western Alps are the only region where extensional, strike-slip and shortening stress regimes coexist over small spatial scales $(10 \mathrm{~s} \mathrm{~km})$, with stress orientations that can vary by several $10 \mathrm{~s}$ of degrees (Sue et al., 1999; Baroux et al., 2001). To first-order, the Alpine stress pattern is consistent with the geodetic deformation, both indicating roughly $\mathrm{E}-\mathrm{W}$ extension in the center of the orogen with shortening in the foreland (Figs. 3, 8 and 9).

Overall, these observations suggest that far-field plateboundary forces are a major control on the continental-scale stress field in metropolitan France and conterminous Western Europe, imprinting a maximum horizontal compression oriented NW-SE to NNW-SSE. The associated deformation regimes oscillate between strike-slip and extension, suggesting a state of stress allowing for easy permutations of the two largest principal stresses $\left(\sigma_{1}\right.$ and $\left.\sigma_{2}\right)$ between vertical and horizontal NW-SE compression (Fig. 9b). Local deviations from this general state, in particular in the Western Alps, point out the important role of additional mechanisms and processes in local deformation.

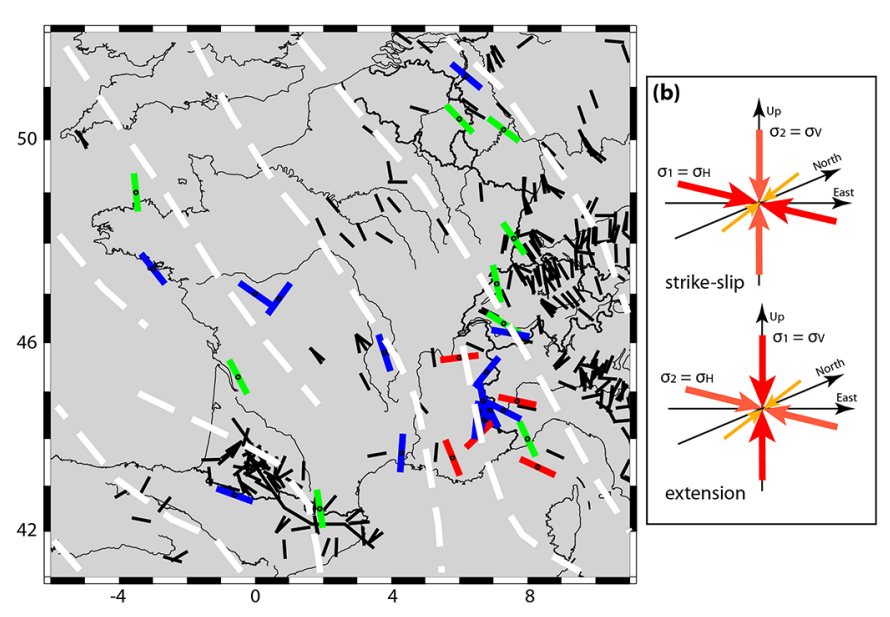

Fig. 9. Orientation of the maximum horizontal compressive stress in metropolitan France and Western Europe. Small solid bars show orientations of in-situ maximum horizontal compressive stress $\left(\sigma_{\mathrm{H}}\right)$ from the World Stress Map (Heidbach et al., 2018). Thick dashed white lines show smoothed $\sigma_{\mathrm{H}}$ orientation. Green, blue and red bars show $\sigma_{H}$ orientation from focal mechanism inversions in strike-slip, extensional and shortening stress regimes. (b) Schema of state of stress with permutations between $\sigma_{1}$ and $\sigma_{2}$ allowing for oscillations between strike-slip and extensional regimes while maintaining $\sigma_{\mathrm{H}}$ orientation.

\subsection{Mantle dynamics, subduction and slab tear}

The potential effects of sub-lithospheric mantle dynamics on present-day deformation in France and Western Europe can be divided in two categories. On a very large spatial scale (hundreds to thousands of $\mathrm{km}$ ), upper mantle convection can contribute to spatial variations of the lithospheric stress orientations and magnitudes. The convection dynamics and complex interactions with slab subduction has likely played a major role in the overall tectonics of the Mediterranean region over the last 30-40 Ma (Faccenna et al., 2014). More specifically, numerical models of mantle convection suggest that asthenosphere-lithosphere coupling may result in NW-SE horizontal compression in most of France, as well as dynamic uplift in the Massif Central (Faccenna and Becker, 2010; Faccenna et al., 2014). However, the efficiency of stress transfer from the asthenosphere to the crust and of dynamic topography related to mantle convection are still largely debated (Coltice et al., 2017).

A second, more local process related to sub-lithospheric dynamics has been proposed to explain the uplift and E-W extension observed in the Western Alps. Seismic tomography images suggest a tear in the subducted European lithosphere, which may have recently detached from the surface in the Western Alps whereas it remains attached in the Eastern Alps. This recent ( $c a$. 2-5 Ma) tear and sinking of the European slab could result in upward flexure, and thus uplift and horizontal extension, of the Alpine crust due to elastic rebound (after removal of the slab weight) and upward flow of hotter asthenosphere (Baran et al., 2014; Fox et al., 2015; Nocquet et al., 2016). Very few quantitative models of deformation associated with a slab-tear rebound exist. They show that the amplitude and spatial wavelength of the crustal deformation 
strongly depends on the assumed material properties and model geometry (Gardi et al., 2010). In all cases, the predicted uplift rates remain small $\left(0.1-0.5 \mathrm{~mm} \mathrm{yr}^{-1}\right)$ compared to those observed by geodesy.

\subsection{Gravitational potential energy}

The third classical process acting on a geological time scale is the gravitational potential energy (GPE), i.e. forces resulting from density contrasts either at the surface (topography) or within the lithosphere. Force-balance and dynamic models show that GPE is a major mechanism in plate boundary regions and potentially in intraplate regions, despite the lower topography (Assameur and Mareschal, 1995; Ghosh et al., 2006). Using geoid height variations as a proxy for GPE, (Camelbeeck et al., 2013) calculate the associated stress integrated over the lithosphere thickness in Western Europe. In their model, GPE stresses vary on spatial scales of a few $10 \mathrm{~s} \mathrm{~km}$ resulting in short-wavelength variations of the tectonic regimes, stress amplitudes (ca. 1-10 MPa) and stress orientations, with two main modes of the maximum horizontal compressive stress $\left(\sigma_{\mathrm{H}}\right)$ roughly NE-SW and NW-SE. These local stress orientations are consistent with most of the World Stress Map data (in-situ and focal mechanisms), highlighting the role of GPE in local stress variations in France and conterminous Western Europe (Heidbach et al., 2007; Camelbeeck et al., 2013).

Additional studies point out the potential role of GPE in the Alps and Pyrenees (Jiménez-Munt et al., 2005; Neres et al., 2018). The high topography of the inner orogen relative to its foreland results in extensional tectonics with the main extension direction (minimum horizontal stress) perpendicular to the local strike of the orogen, consistent with the present-day deformation observed in geological, seismological, and geodetic data. On smaller scales, GPE may also be linked with seismicity clusters in the central Pyrenees in association with the subsidence of a block of dense lower crust trapped within the upper crust (Souriau et al., 2014), and in southern Western Alps where GPE may drive the southward flow of the sedimentary cover over a Trias decollement level (Le Pichon et al., 2010). Altogether, these studies are part of the ongoing debate regarding the concept of gravitational collapse and its applicability to the Alps and Pyrenees (Selverstone, 2005; Vernant et al., 2013).

A major hypothesis of the GPE models is local isostatic equilibrium, i.e., a negligible support of the topography and density loads by the lithosphere strength. This assumption is contradicted by studies of gravity - topography coherence or admittance that indicate an effective elastic thickness of the lithosphere of 10-40 km over most of Western Europe (PérezGussinyé and Watts, 2005; Tesauro et al., 2009). Thus, short wavelength loads $(<c a .100 \mathrm{~km})$ should be mostly supported by the lithosphere flexural rigidity with limited GPE effect, whereas long wavelength loads $(>100-200 \mathrm{~km}$, such as the Alps or Pyrenees) may result in much stronger GPE effects. Mechanical models including lithosphere elasticity indicate that the topography and crustal loads in the central Pyrenees result in very little effect on the modeled deformation (Genti et al., 2016).

\subsection{Erosion}

Coupling between erosion, crustal deformation and climate has been proposed on timescales ranging from geological (1$10 \mathrm{Myr}$ ) to human (1-10 yr) periods (Dadson et al., 2003; Willett et al., 2006; Steer et al., 2014). In practice, erosion rates (i.e., rates at which material is being removed and transported away from the area of interest) are only estimated through proxy analyses. Sediment budgets in deposition basins and exhumation models based on low-temperature thermochronology provide estimations of erosion rates over periods of a few Myr. At intermediate timescales, denudation of river catchment basins estimated using cosmogenic nuclide exposition are used as a proxy for erosion rates over a few kyr. Present-day sediment fluxes in river transport are used to estimate erosion rates over a few $10 \mathrm{~s}$ yr. These techniques only provide indirect estimations of erosion rates averaged over the considered time period and that depend on models with multiple unknowns.

In France and conterminous Western Europe, long-term erosion has been proposed as a possible driver of present-day uplift and extension in the Alps and Pyrenees (Champagnac et al., 2007; Vernant et al., 2013). For the latter, slow erosion rates $\left(<0.1 \mathrm{~mm} \mathrm{yr}^{-1}\right)$ are estimated for the post-orogenic period (Neogene). Exhumation models suggest very slow ( $c$ a. $0.02 \mathrm{~mm} \mathrm{yr}^{-1}$ ) erosion rates averaged over the last $30 \mathrm{Ma}$ (Fillon and van der Beek, 2012). Slightly faster ( $c a$. 0.05$0.1 \mathrm{~mm} \mathrm{yr}^{-1}$ ) erosion rates are proposed for the last 1000 $10 \mathrm{ka}$ in the easternmost Pyrenees on the basis of cosmogenic dating and morphometric analyses (Molliex et al., 2016). Mechanical models show that these very slow erosion rates, combined with isostatic re-equilibrium of the over-compensated crustal root, can result in slow uplift and extension rates in the Pyrenees compatible with the geodetic and seismicity observations (Genti et al., 2016).

A larger body of work exists in the Alps that provides a more detailed picture of erosion rates, although spatial and temporal variations remain debated, in particular regarding the potential acceleration of erosion rates in the last 1-5 Ma due to the Late Neogene glaciations and wetter climate. Estimations of exhumation rates from low-temperature thermochronology vary between less than $0.4 \mathrm{~mm} \mathrm{yr}^{-1}$ and over $1.0 \mathrm{~mm} \mathrm{yr}^{-1}$ in the Western and Central Alps, with indications of either steadystate rates since $c a$. $15 \mathrm{Ma}$ or acceleration over the last $2-5 \mathrm{Ma}$ (Glotzbach et al., 2011; Glotzbach et al., 2013; Fox et al., 2015; Molliex et al., 2016). On a shorter timescale, denudation data indicate average erosion rates of the same magnitude ( $\mathrm{ca}$. $0.5-1.0 \mathrm{~mm} \mathrm{yr}^{-1}$ ) over the last $5-20 \mathrm{ka}$, with a possible increase associated to the last deglaciation (Glotzbach et al., 2013; Molliex et al., 2016). Mechanical models show that the uplift response to erosion reaches $0.1-0.5 \mathrm{~mm} \mathrm{yr}^{-1}(50-80 \%$ of the erosion rates), i.e. at most $30-50 \%$ of the observed uplift velocities, depending on the mechanical parameterization on the lithosphere (Champagnac et al., 2007; Mey et al., 2016).

Erosion estimations are sparse in other regions of metropolitan France. Denudation measurements in the river catchments flowing from the Massif Central indicate erosion rates ca. $0.05-0.08 \mathrm{~mm} \mathrm{yr}^{-1}$, about an order of magnitude slower than the Western Alps and slightly slower than the 
Pyrenees (Schaller et al., 2001; Olivetti et al., 2016). Slower rates $c a .0 .01-0.05 \mathrm{~mm} \mathrm{yr}^{-1}$ are estimated in the Ardennes and Rhine Graben region (Schaller et al., 2001). A simple linear scaling suggests that uplift and extension in response to erosion in these regions should be about 10 times smaller than in the Western Alps and about 2-5 times smaller than in the Pyrenees.

\subsection{Glacial isostatic adjustment}

Glacial isostatic adjustment (GIA), also referred to as postglacial rebound, is the response of the solid Earth to surface loading and unloading associated with fluctuations of icecaps, glaciers and sea level at periods controlled by orbital forcing (ca. 23, 42 and $100 \mathrm{kyr}$; (Hays et al., 1976)). In Europe, Quaternary ice systems comprise the Fennoscandian and Celtic icecaps that covered Scandinavia and most of the British Isles, as well as smaller icecaps and mountain glaciers in regions of high altitude such the Alps and, to a much smaller extent, the Pyrenees and Massif Central (Florineth and Schlüchter, 2000; Patton et al., 2016). Since the Last Glacial Maximum (LGM, ca. 18-20 ka), GIA induces large deformations in northern Europe in response to the melting of the Fennoscandian icecap (e.g., present-day uplift rates up to 10 $15 \mathrm{~mm} \mathrm{yr}^{-1}$ in central Scandinavia). This GIA-related deformation corresponds to first order to a viscoelastic process and may be responsible for large Holocene earthquakes $(\mathrm{M}=7-8)$ in Scandinavia and as far south as central Germany (Steffen et al., 2014; Brandes et al., 2015).

Although smaller than in northern Europe, the impact of LGM glaciations in metropolitan France and neighboring regions may be associated with deformation and seismicity on two levels: at a very large spatial scale (ca. $1000 \mathrm{~km}$ ) in response to the Fennoscandian icecap, and at a more local scale $(10-100 \mathrm{~km})$ in response to the Alpine icecap and glaciers. For the former, geodetic data and numerical models indicate that the effect of the northern icecaps is likely limited to small subsidence rates $\left(<1 \mathrm{~mm} \mathrm{yr}^{-1}\right)$ and NE-SW shortening rates $\left(<1 \times 10^{-9} \mathrm{yr}^{-1}\right)$ in Belgium and southwestern Germany (Nocquet et al., 2005; van Camp et al., 2011; Peltier et al., 2015). In metropolitan France, the Fennoscandian GIA signal is likely at the limit of, or smaller than the resolution of geodetic data.

In the Alps, the LGM icecap covered most of the mountain range, with the exception of the southern Western Alps, with an average ice thickness $c a .500 \mathrm{~m}$ and maximums up to $1.5 \mathrm{~km}$ in the main valleys (Mey et al., 2016). Because of the relatively small dimensions of the Alpine icecap, standard GIA models yield very small present-day deformations, with at most $0.5 \mathrm{~mm} \mathrm{yr}^{-1}$ of uplift in the center of the Alps (Stocchi et al., 2005). In contrast, recent more complex models include spatial variations of the lithosphere rheology and in particular thinning of the elastic layer beneath the Alps (Chéry et al., 2016; Mey et al., 2016). These models result in faster present-day GIA deformation: uplift rates $c a$. $1-2 \mathrm{~mm} \mathrm{yr}^{-1}$ and $\mathrm{E}-\mathrm{W}$ extension in the inner region of the Western Alps transitioning to near-zero vertical motion and shortening in the foreland, consistent in amplitude and style with the geological, seismicity and geodetic data.

\subsection{Anthropic activities}

Seismic events related to human activity represent about one third of all earthquakes in metropolitan France between 1962 and 2009 (Cara et al., 2015). Most are quarry blasts with small magnitude $(c a . \mathrm{M}<3)$ and very limited spatial impact (few 10-100 s m). Other anthropic activities such as oil and gas extraction, geothermal production or hydro dams can result in triggering of larger earthquakes over wider areas (Foulger et al., 2018). In the last case, the effects of loading/unloading of hydro dams (or other surface mass modifications) are commonly associated with stress perturbations that affect faults already at near-failure stress equilibrium (Grasso et al., 1992). In metropolitan France, several areas present evidence of anthropic deformation and seismicity on levels that warrant geodetic and seismic monitoring. The Lacq gas field, southwestern France, is a typical case of human-induced deformation associated with the exploitation of hydrocarbons. Between 1974 and 1992, gas production resulted in over 2000 earthquakes (up to $\mathrm{M}=4.2$ ) and subsidence up to $5 \mathrm{~cm}$ in an area $c a .10 \times 20 \mathrm{~km}$ (Bardainne et al., 2008). Alternatively, examples of significant subsidence with little to no seismicity are observed in both solution and tunnel mining systems (Guéguen et al., 2009). Induced seismicity associated with geothermal energy production, and in particular enhanced geothermal systems, is also an important and ongoing subject of research in France and Western Europe (Majer et al., 2007). Because of its complex and specific characteristics, anthropic generation of deformation and seismicity is beyond the scope of this review.

\section{Discussion}

The preceding review highlights the intricacies of seismicity and deformation processes in metropolitan France and neighboring Western Europe, synthesized in Figure 10. The consistency of in situ stress data and earthquake focal mechanisms suggests that far-field tectonic forces are a major factor defining the large-scale crustal stress pattern (maximum horizontal compression, Fig. 9). Yet, non-tectonic processes such as erosion and glacial isostatic adjustment must play an important role in local and regional variations in seismicity and deformation, in particular in relation with orogen-normal extension in the Alps and Pyrenees. In addition, local gravitational forces from topography or mantle dynamics may also contribute in specific areas such as the Alps.

Mechanical numerical modeling is a critical approach to address and decipher the complexities of present-day deformation and the relative contributions of the various driving processes. This is especially true when considering the additional complexities of crustal and mantle rheologies derived from variations in thickness, composition, geotherm or tectonic history. As an example, the present-day response to deglaciation in the Alps can vary by a factor of five depending on the presence of weak crustal and mantle domains related to the Alpine tectonics (Chéry et al., 2016). This potential role of structural inheritance in present-day deformation and seismicity is reviewed in the next section. We then discuss the difficulties of integrating this wealth of information in future seismic hazard calculations. 


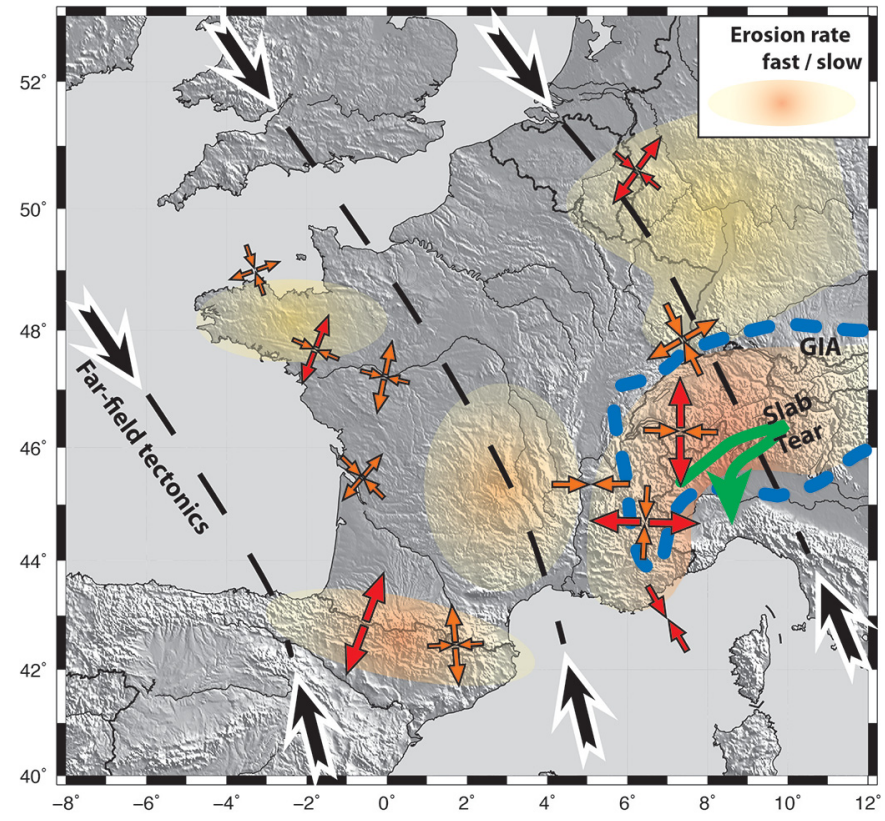

Fig. 10. Schematic synthesis of present-day deformation and driving processes in metropolitan France and Western Europe. Red (resp. orange) crosses show the styles and relative amplitudes of wellconstrained (resp. probable) present-day horizontal deformation from earthquake focal mechanisms and geodetic data. Black dashed lines and arrows show the large-scale NW-SE horizontal compression from far-field tectonic forces. Blue dashed line shows the area impacted by Glacial Isostatic Adjustment (GIA) from the Alpine ice cap. Curved green arrow shows the area affected by the European slab tear and associated mantle dynamics. Orange shadings show areas affected by long-term erosion $($ red-yellow $=$ fast-slow $)$.

\subsection{Role for structural inheritance}

In continental intraplate regions, a first-order spatial correlation between seismicity and structural inheritance is observed and discussed since the 1970s (Sykes, 1978; Johnston, 1989). In these studies, structural inheritance is commonly defined as lithospheric-scale geological structures associated with past major tectonic events (commonly Paleozoic or older) and large strain affecting regions of 10$100 \mathrm{~s} \mathrm{~km}$. Depending on the metrics and definitions, 55-95\% of intraplate seismicity occurs in regions of strong structural inheritance such as paleo-rifts and passive margins (Johnston, 1989; Schulte and Mooney, 2005). To a first-order, a spatial correlation between seismicity and structural inheritance can also be observed in metropolitan France (Fig. 11). Background micro-seismicity and $\mathrm{M}_{\mathrm{W}} \geq 4.5$ earthquakes occur preferentially within $c a .50 \mathrm{~km}$ of fault systems affecting the Moho and the Variscan basement: e.g., the South Armorican Fault Zone, the North Pyrenean Fault, the Pennic Front Thrust and Belledonne Fault, the Lower Rhine Fault System. Exceptions to this correlation are of two types: (1) seismicity occurring in regions where structural inheritance is limited to shallow, thinskin tectonics (Jura and Alpine foreland) and (2) regions of major structural inheritance with little to no seismicity (e.g., Bray Fault, Cévennes Fault).

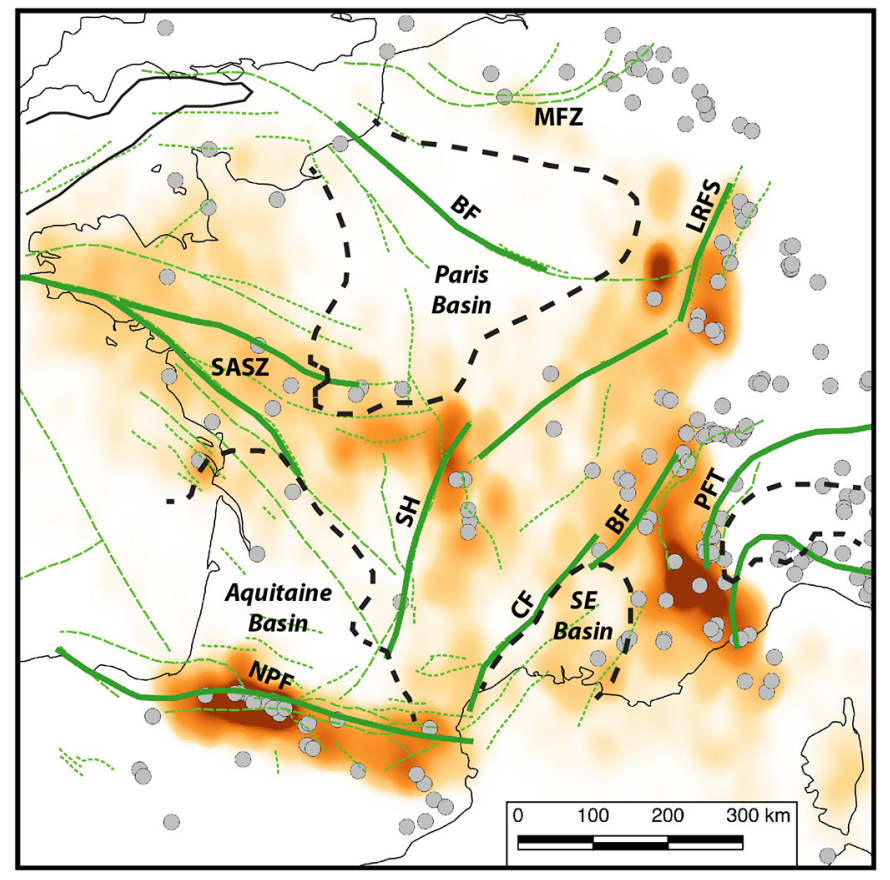

Fig. 11. Relationship between structural inheritance and seismicity in metropolitan France. Solid and dashed green lines show major crustal faults and fault zones (MFZ: Midi Fault Zone; BF: Bray Fault; LRFS: Lower Rhine Fault System; SASZ: South Armorican shear Zone; SH: Sillon Houiller; NPF: North Pyrenees Fault; CF: Cévennes Fault; BF: Belledonne Fault; PFT: Pennic Front Thrust). Solid dashed lines show major sedimentary basins. Grey circles show historical and instrumental earthquakes ( $\mathrm{Mw} \geq 4.5$, SHARE catalogue). Orange shading shows relative density of instrumental earthquakes (Mw $\geq 2.0$, SI-Hex catalogue).

This first-order correlation between intraplate seismicity and structural inheritance is commonly related to mechanical weakening and thus strain concentration within the lithosphere in paleo-tectonic domains (Sykes, 1978; Mazzotti, 2007). Geological studies of exposed shear zones indicate that in the lithospheric mantle this mechanical weakening is related to olivine crystal alignment or grain-size reduction during past tectonic events (Précigout and Gueydan, 2009; Tommasi et al., 2009). In the crust, the primary mechanism for mechanical weakening is the nucleation of mineral layering (e.g., mica, talc) in fault and shear zones (Gueydan et al., 2003; Holdsworth, 2004). These various mechanisms can result in permanent strength reduction up to factors of $10-100$ or more.

Few studies provide quantitative analyses of the potential relationship between structural inheritance weakening and amplification of present-day deformation and seismicity. $A d$ hoc weak zones have been tested in numerical models of glacial isostatic adjustment by reducing the mantle viscosity or elastic plate thickness in regions of structural inheritance (Grollimund and Zoback, 2001; Wu and Mazzotti, 2007; Chéry et al., 2016). They show that strength reduction by an order of magnitude can result in a concentration and increase of GIA deformation by factors $c a$. 2-10 depending on the model assumptions. More complex numerical models that integrate specific rheological laws for the weakening mechanisms are 
also developed (Mazzotti and Gueydan, 2018; Tarayoun et al., 2019). In these models, the impact of structural inheritance on present-day deformation strongly depends on the amplitude and location of the weak zones, but also on the characteristics of the forcing mechanisms (e.g., long-term tectonics or transient GIA). However, these initial studies suggest that spatial variations in present-day deformation rates, and thus seismicity rates, may be limited to factor of $c a .2-25$ in intraplate regions such as metropolitan France (Tarayoun et al., 2019). The implications of such constraints on seismicity and seismic hazard remain to be addressed.

Finally, an apparent anti-correlation is observed between seismicity and the presence of large sedimentary basins. The Paris and Aquitaine basins are associated with very low background seismicity, although they host a few large earthquakes $(\mathrm{Mw} \geq 4.0)$ and neotectonic deformation evidence (Figs. 5 and 11). The effect of these large Meso-Cenozoic basins as potential inhibitors of present-day deformation and seismicity remains to be studied. It is worth noting that the South-East Basin does not show a similar anti-correlation.

\subsection{Seismic hazard implications}

As shown in the previous sections, the characterization of seismicity in metropolitan France and Western Europe faces numerous complexities and unknowns, from the driving processes and role of structural inheritance in strain localization, to the amplitude and time variability of long- and shortterm deformation rates, or the identification of potential active faults and large earthquake recurrence. Hence, as for all continental intraplate regions, seismic hazard assessment remains a major challenge both from scientific and societal perspectives. This issue is perfectly illustrated by the plethora of articles and reports published in the last 20 years on the subject of seismic hazard in the New Madrid Seismic Zone, eastern USA. Although it is probably the best studied intraplate system, the validity of its current probabilistic seismic hazard calculations and their applicability to official policies are the subject of fierce debates (Frankel, 2004; Wang and Cobb, 2012).

In France, seismic hazard calculations have been performed by public institutes and private companies using deterministic or probabilistic methods, depending on the regulations and applications (Dominique et al., 1998; Marin et al., 2004). Most of these studies rely on classical definitions of seismotectonic zones that represent "tectonically coherent regions" (Grellet et al., 1993; Baize et al., 2013), with recent developments focusing on the integration of individual seismogenic faults (Cushing et al., 2008; Jomard et al., 2017). In the case of probabilistic hazard assessment, the calculations require the definition of local earthquake frequencies of occurrence. Thus, a robust knowledge of deformations rates (regional strain or individual fault slip) and their uncertainties is critical to these models (Chartier et al., 2017). In the case of deterministic calculations, the seismotectonic framework also provides important constraints on the local maximum magnitude, predominant earthquake mechanism, etc., to compensate for the limited knowledge on large historical earthquakes and paleo-earthquakes in France.
The quantitative integration of deformation rates derived from geodetic data or numerical models is becoming an important aspect of seismic hazard assessment, especially in regions of fast deformation such as plate boundary zones (Field et al., 2014; Evans, 2017). However, the complexity and probable role of non-tectonic processes result in additional difficulties in metropolitan France and neighboring Western Europe, as in most continental intraplate regions (Atkinson, 2007; Mazzotti, 2018). In particular, major issues remain to be addressed before deformation rates due to loading/unloading processes, such as erosion and glacial isostatic adjustment (GIA), can be included in seismic hazard models. Such processes are associated with smooth deformation patterns controlled in part by the elastic response of the lithosphere, i.e., deformation on spatial scales of 10-100 s km and partly to fully aseismic. On a global scales, comparisons of seismic and geodetic strain rates indicate a very large variability of the seismic/aseismic deformation ratio (Mazzotti, 2018). In addition, recent advances in geodetic data analysis also suggest that this ratio may be strongly affected by the presence of major structural inheritance (Tarayoun et al., 2018).

Finally, the probable role of non-tectonic environmental processes such as erosion and GIA also raises the issue of timedependent deformation and thus seismic hazard. Orbital forcing on climate yields a strong variability of glaciation and erosion rates on time scales of $1-10 \mathrm{kyr}$, but shorter modulations also exist on time scales of 1-100 yr (e.g., Little Ice Age or Mediterranean High Precipitation Events). The impact of these time-varying forcing mechanisms on deformation and earthquake triggering or earthquake clustering is starting to be addressed in active regions (Steer et al., 2017). Their potential effects in metropolitan France remain to be studied.

\section{Conclusion}

Research in the last decades has brought to light the intricacies of seismicity, present-day deformation and the related driving processes in metropolitan France and conterminous Western Europe (Fig. 10). In particular, new geological, seismological and geodetic data show that the Pyrenees and Western Alps currently experience orogennormal extension $c a .0 .5 \mathrm{~mm} \mathrm{yr}^{-1}$ unrelated to their Cenozoic tectonic history of convergence and mountain building. Elsewhere, present-day deformation remains more elusive. Deformation styles, derived from earthquake focal mechanisms, vary mainly between extension and strike-slip, with shortening limited to the Western Alps foreland. Geodetic data have so far only provided upper bounds on the deformation rates (less than $0.2-0.5 \mathrm{~mm} \mathrm{yr}^{-1}$ over $100-200 \mathrm{~km}$ ), but the drastic improvements in data density and analysis methods suggest that significant deformation velocities can now be resolved in most of metropolitan France and western Europe.

The numerous studies and observations reviewed here point to the first, and possibly most important, conclusion that plate tectonics and its classical mechanisms (relative plate motions, mantle convection) are not the primary drivers of present-day deformation and seismicity in metropolitan France. Additional processes must play a major role in the 
regional and local complexities. A variety of potential candidates exists in different regions, ranging from long-term processes (e.g., potential energy from density contrasts and topography, slab tear propagation) to non-tectonic transient processes acting on time scales from the Myr to the $\operatorname{kyr}(e . g$., erosion, glacial isostatic adjustment). Due to this variety of potential driving processes, the relationship between ongoing deformation and seismicity - and thus seismic hazardremains a key uncertainty. Whether long-term deformation results in very slow fault loading rates and recurring earthquakes with very long return periods, or whether present-day loading is negligible and large earthquakes may not be recurring remains an open question, potentially with different answers in different regions of metropolitan France and conterminous Western Europe. It is worth noting that these various processes likely also play a role in plate boundary zones. On a large scale, their contributions are generally overshadowed by standard plate tectonics, but detailed studies commonly point out the local importance of additional processes such as GIA or slab tear in plate boundary systems.

The relationships between driving processes, deformation and seismicity need to be addressed through mechanical numerical modeling in order to take advantage of the geological, seismological and geodetic data that will continue to improve in the near future. In particular, recent studies show that structural inheritance (crust or mantle strength variability due tectonic history) can play a major role in the localization and amplification of deformation and thus seismicity. A full integration of numerical models, geodetic, seismological and geological data within a consistent seismotectonic framework is a next step that should be supported at the scale of France and Western Europe (cf. (Field et al., 2014) for the California example). In particular, macroseismic data and archeo- and historical earthquake catalogs are fundamental to better define the spatial and temporal characteristics of seismicity in metropolitan France; studies of historical data need to be resumed and supported.

Acknowledgements. This article is part of an ongoing effort of the RESIF (Réseau Sismologique and Géodésique Français) research infrastructure to bring together the various communities that can contribute to better understand seismicity in France (https://www.resif.fr). Ideas for this review originated during a series of workshops on seismic hazard and seismotectonics in France organized between 2017 and 2019 by the RESIF "Action Transverse Sismicité" (https:// www.resif.fr/spip.php?article144). We thank the numerous colleagues who participated to the workshops and contributed to the discussions regarding the seismicity, deformation and their driving mechanisms, with special thanks to Oona Scotti for her support with these workshops. The data and results presented in this review were only possible thanks to the institutions and organizations that for decades have provided financial and human resources for the observation and study of seismicity of metropolitan France (in an almost general indifference). Figures in this article were made using GMT 5 (Wessel et al., 2013), R (R Core Team, 2019) and QGIS (QGIS Development Team, 2019) software. We thank an anonymous reviewer, Romain Jolivet and the editors for their comments and suggestions.

\section{References}

Adjadj F, Helly B, Lauxerois R. 2014. Carte archéologique de la Gaule 38/3. Vienne, Paris, France.

Amorèse D, Benjumea J, Cara M. 2020. Source parameters of the 1926 and 1927 Jersey earthquakes from historical, instrumental, and macroseismic data. Physics of the Earth and Planetary Interiors 300: 106420. https://doi.org/10.1016/j.pepi.2019.106420.

Asensio E, Khazaradze G, Echeverria A, King RW, Vilajosana I. 2012. GPS studies of active deformation in the Pyrenees. Geophysical Journal International 190: 913-921. https://doi.org/ 10.1111/j.1365-246X.2012.05525.x.

Assameur DM, Mareschal J-C. 1995. Stress induced by topography and crustal density heterogeneities: implication for the seismicity of southeastern Canada. Tectonophysics 241: 179-192.

Atkinson GM. 2007. Challenges in seismic hazard analysis for continental interior. In: Stein S, Mazzotti S, eds. Geological Society of America-Special Papers 425: 329-345. https://doi.org/ 10.1130/2007.2425(21).

Baize S, Cushing EM, Lemeille F, Jomard H. 2013. Updated seismotectonic zoning scheme of Metropolitan France, with reference to geologic and seismotectonic data. Bulletin de la Societe Geologique de France 184: 225-259. https://doi.org/ 10.2113/gssgfbull.184.3.225.

Bakun WH, Scotti O. 2006. Regional intensity attenuation models for France and the estimation of magnitude and location of historical earthquakes. Geophysical Journal International 164: 596-610. https://doi.org/10.1111/j.1365-246X.2005.02808.x.

Baran R, Friedrich AM, Schlunegger F. 2014. The late Miocene to Holocene erosion pattern of the Alpine foreland basin reflects Eurasian slab unloading beneath the western Alps rather than global climate change. Lithosphere 6: 124-131. https://doi.org/ 10.1007/s00015-009-1306-4.

Bardainne T, Dubos-Sallée N, Sénéchal G, Gaillot P, Perroud H. 2008. Analysis of the induced seismicity of the Lacq gas field (Southwestern France) and model of deformation. Geophysical Journal International 172: 1151-1162. https://doi.org/10.1111/ j.1365-246X.2007.03705.x.

Baroux E, Béthoux N, Bellier O. 2001. Analyses of the stress field in southeastern France from earthquake focal mechanisms. Geophysical Journal International 145: 336-348.

Baroux E, Pino NA, Valensise G, Scotti O, Cushing EM. 2003. Source parameters of the 11 June 1909, Lambesc (Provence, southeastern France) earthquake: A reappraisal based on macroseismic, seismological, and geodetic observations. Journal of Geophysical Research: Solid Earth 108: 1-23. https://doi.org/10.1029/2000JB900259.

Baumont D, Manchuel K, Traversa P, Durouchoux C, Nayman E, Ameri G. 2018. Intensity predictive attenuation models calibrated in Mw for metropolitan France. Bulletin of Earthquake Engineering 16: 2285-2310. https://doi.org/10.1007/s10518-018-0344-6.

Beck C. 2009. Late Quaternary lacustrine paleo-seismic archives in north-western Alps: Examples of earthquake-origin assessment of sedimentary disturbances. Earth-Science Reviews 96: 327-344. https://doi.org/10.1016/j.earscirev.2009.07.005.

Bertil D, Terrier M. 2017. Élaboration d'une méthodologie d'estimation de l'activité des failles-Phase 1: synthèse des méthodes sur l'identification et la classification des failles actives. Rapport final, 148 p. BRGM/RP-67434-FR.

Brandes C, Steffen H, Steffen R, Wu P. 2015. Intraplate seismicity in northern Central Europe is induced by the last glaciation. Geology 43: 611-614. https://doi.org/10.1130/G36710.1.

Brockmann E, Ineichen D, Marti U, Schaer S, Schlatter A. 2012. Determination of tectonic movements in the Swiss Alps using 
GNSS and levelling. In: Kenyon S, Pachino M, Marti U, eds. Geodesy for Planet Earth, International Association of Geodesy Symposia, Berlin, Heidelberg, pp. 689-695.

Calais E, Bayer R, Chéry J, Cotton F, Doerflinger E, Flouzat M, et al. 2000a. Regal : réseau GPS permanent dans les Alpes occidentales. Configuration et premiers résultats. Comptes Rendus de l'Académie des Sciences-Series IIA-Earth and Planetary Science 331: 435-442.

Calais E, Galisson L, Stéphan JF, Delteil J, Derverchère J, Larroque C, et al. 2000b. Crustal strain in the Southern Alps, France, 19481998. Tectonophysics 319: 1-17.

Calais E, Camelbeeck T, Stein S, Liu M, Craig TJ. 2016. A new paradigm for large earthquakes in stable continental plate interiors. Geophysical Research Letters 43: 10621-10637. https://doi.org/ 10.1002/2016GL070815.

Camelbeeck T, de Viron O, van Camp M, Kusters D. 2013. Local stress sources in Western Europe lithosphere from geoid anomalies. Lithosphere 5: 235-246. https://doi.org/10.1130/L238.1.

Cara M, Alasset P-J, Sira C. 2008. Magnitude of historical earthquakes, from macroseismic data to seismic waveform modelling: application to the Pyrenees and a 1905 earthquake in the Alps. In: Fréchet J, Meghraoui M, Stucchi M, eds. Historical Seismology. Dordrecht: Springer Netherlands, pp. 369-384.

Cara M, et al. 2015. SI-Hex: a new catalogue of instrumental seismicity for metropolitan France. Bulletin de la Société Géologique de France 186: 3-19.

Cara M, Denieul M, Sèbe O, Delouis B, Cansi Y, Schlupp A. 2017. Magnitude Mw in metropolitan France. Journal of Seismology 21 (3): 551-565. https://doi.org/10.1007/s10950-016-9617-1.

Champagnac J-D, Molnar P, Anderson RS, Sue C, Delacou B. 2007. Quaternary erosion-induced isostatic rebound in the western Alps. Geology 35: 195-198. https://doi.org/10.1130/G23053A.1.

Chardon D, Hermitte D, Nguyen F, Bellier O. 2005. First paleoseismological constraints on the strongest earthquake in France (Provence) in the twentieth century. Geology 33: 901. https://doi.org/10.1130/G21713.1.

Chartier T, Scotti O, Clément C, Jomard H, Baize S. 2017. Transposing an active fault database into a fault-based seismic hazard assessment for nuclear facilities-Part 2: Impact of fault parameter uncertainties on a site-specific PSHA exercise in the Upper Rhine Graben, eastern France. Natural Hazards and Earth System Sciences 17: 1585-1593. https://doi.org/10.5194/nhess17-1585-2017.

Chéry J, Genti M, Vernant P. 2016. Ice cap melting and low-viscosity crustal root explain the narrow geodetic uplift of the Western Alps. Geophysical Research Letters 43: 1-8. https://doi.org/10.1002/ 2016GL067821.

Clark D, McPherson A, Van Dissen R. 2012. Long-term behaviour of Australian stable continental region (SCR) faults. Tectonophysics 566-567: 1-30. https://doi.org/10.1016/j.tecto.2012.07.004.

Coltice N, Gérault M, Ulvrová M. 2017. A mantle convection perspective on global tectonics. Earth Science Reviews 165: 120150. https://doi.org/10.1016/j.earscirev.2016.11.006.

Combes P, Carbon D, Cushing EM, Granier T, Vaskou P. 1993. Mise en évidence d'un paléoséisme pléistocène supérieur dans la vallée du Rhône, implications sur les connaissances de la sismicité en France. Comptes Rendus de l'Académie des Sciences-Series IIA-Earth and Planetary Science 317: 689-696.

Cushing EM, Bellier O, Nechtschein S, Sébrier M, Lomax A, Volant, $\mathrm{P}$, et al. 2008. A multidisciplinary study of a slow-slipping fault for seismic hazard assessment: the example of the Middle Durance Fault (SE France). Geophysical Journal International 172: 11631178. https://doi.org/10.1111/j.1365-246X.2007.03683.x.
Dadson SJ, Hovius N, Chen H, Dade WB, Hsieh M-L, Willett SD, et al. 2003. Links between erosion, runoff variability and seismicity in the Taiwan orogen. Nature 426: 648-651. https://doi.org/ 10.1038/nature02150.

D’Agostino N, Avallone A, Cheloni D, D'Anastasio E, Mantenuto S, Selvaggi G. 2008. Active tectonics of the Adriatic region from GPS and earthquake slip vectors. Journal of Geophysical Research: Solid Earth 113: B09401. https://doi.org/10.1029/2008JB005860.

De Barros L, Baques M, Godano M, Helmstetter A, Deschamps A, Larroque C, et al. 2019. Fluid-Induced Swarms and Coseismic Stress Transfer: A Dual Process Highlighted in the Aftershock Sequence of the 7 April 2014 Earthquake (Ml 4.8, Ubaye, France). Journal of Geophysical Research: Solid Earth 124: 3918-3932. https://doi.org/10.1029/2018JB017226.

de La Taille C, Jouanne F, Crouzet C, Beck C, Jomard H, de Rycker K, et al. 2015. Impact of active faulting on the post LGM infill of Le Bourget Lake (western Alps, France). Tectonophysics 664: 31-49. https://doi.org/10.1016/j.tecto.2015.08.024.

Delouis B, Haessler H, Cisternas A, Rivera L. 1993. Stress tensor determination in France and neighbouring regions. Tectonophysics 221: 413-437.

DeMets C, Gordon RG, Argus DF. 2010. Geologically current plate motions. Geophysical Journal International 181: 1-80. https://doi. org/10.1111/j.1365-246X.2009.04491.x.

Dominique P, Autran A, Bles J, Fitzenz D, Samarcq F, Terrier M, et al. 1998. Probabilistic seismic hazard assessment in France, Part 2: probabilistic approach: seismic hazard map on the national territory (France). Balkema, Rotterdam, Paris, France.

Dow JM, Neilan RE, Rizos C. 2009. The International GNSS Service in a changing landscape of Global Navigation Satellite Systems. Journal of Geodesy 83: 191-198. https://doi.org/10.1007/ s00190-008-0300-3.

Evans EL. 2017. Using strain rates to forecast seismic hazards. Eos 98. https://doi.org/10.1029/2017EO067343.

Faccenna C, Becker TW. 2010. Shaping mobile belts by small-scale convection. Nature 465: 602-605. https://doi.org/10.1038/na ture09064.

Faccenna C, Becker TW, Auer L, Billi A, Boschi L, Brun J-P, et al. 2014. Mantle dynamics in the Mediterranean. Review of Geophysics 52: 283-332. https://doi.org/10.1002/(ISSN) 1944-9208

Ferhat G, Feigl K, Ritz J-F, Souriau A. 1998. Geodetic measurement of tectonic deformation in the southern Alps and Provence, France, 1947-1994. Earth and Planetary Science Letters 159: 35-46.

Ferhat G, Portier N, Hinderer J, Calvo Garcia-Maroto M, Abdelfettah Y, Riccardi U. 2017. Three years of monitoring using leveling and hybrid gravimetry applied to geothermal sites of Soultz-sousForêts and Rittershoffen, Rhine Graben, France. In: Intern. Conf. Eng. Surv., Lisbon, Portugal.

Ferry M, Meghraoui M, Delouis B, Giardini D. 2005. Evidence for Holocene palaeoseismicity along the Basel-Reinach active normal fault (Switzerland): a seismic source for the 1356 earthquake in the Upper Rhine graben. Geophysical Journal International 160: 554 572. https://doi.org/10.1111/j.1365-246X.2005.02404.x.

Field EH, Arrowsmith RJ, Biasi GP, Bird P, Dawson TE, Felzer KR, et al. 2014. Uniform California Earthquake Rupture Forecast, Version 3 (UCERF3) - The Time-Independent Model. Bulletin of the Seismological Society of America 104: 1122-1180. https://doi. org/10.1785/0120130164.

Fillon C, van der Beek PA. 2012. Post-orogenic evolution of the southern Pyrenees: constraints from inverse thermo-kinematic modelling of low-temperature thermochronology data. Basin Research 24: 418436. https://doi.org/10.1111/j.1365-2117.2011.00533.x. 
Florineth D, Schlüchter C. 2000. Alpine Evidence for Atmospheric Circulation Patterns in Europe during the Last Glacial Maximum. Quaternary Research 54: 295-308. https://doi.org/10.1006/ qres.2000.2169.

Foulger GR, Wilson MP, Gluyas JG, Julian BR, Davies RJ. 2018. Global review of human-induced earthquakes. Earth-Science Reviews 178: 438-514. https://doi.org/10.1016/j.ear scirev.2017.07.008.

Fourniguet J. 1980. Mouvements verticaux actuels en Bassin de Paris révélés par les combinaisons de nivellements. Bulletin de la Société Géologique de France 4: 685-693.

Fox M, Herman F, Kissling E, Willett SD. 2015. Rapid exhumation in the Western Alps driven by slab detachment and glacial erosion. Geology 43: 379-382. https://doi.org/10.1130/G36411.1.

Frankel A. 2004. How can seismic hazard around the New Madrid seismic zone be similar to that in California? Seismological Research Letters 75: 575-586.

Fuhrmann T, Caro Cuenca M, Knöpfler A, van Leijen FJ, Mayer M, Westerhaus M, et al. 2015. Estimation of small surface displacements in the Upper Rhine Graben area from a combined analysis of PS-InSAR, levelling and GNSS data. Geophysical Journal International 203: 614-631. https://doi.org/10.1016/0040-1951 (92)90338-7.

Gardi A, Baize S, Scotti O. 2010. Present-day vertical isostatic readjustment of the Western Alps revealed by numerical modelling and geodetic and seismotectonic data. Geological Society, London, Special Publications 332: 115-128. https://doi.org/10.1144/ SP332.8.

Genti M, Chéry J, Vernant P, Rigo A. 2016. Impact of gravity forces and topography denudation on normal faulting in Central-Western Pyrenees: Insights from 2D numerical models. Comptes rendusGeoscience 348: 173-183. https://doi.org/10.1016/j. crte.2015.08.004.

Ghosh A, Holt WE, Flesch LM, Haines AJ. 2006. Gravitational potential energy of the Tibetan Plateau and the forces driving the Indian plate. Geology 34: 321. https://doi.org/10.1130/G22071.1.

Glotzbach C, Bernet M, van der Beek P. 2011. Detrital thermochronology records changing source areas and steady exhumation in the Western European Alps. Geology 39: 239-242. https://doi.org/ 10.1130/G31757.1.

Glotzbach C, van der Beek P, Carcaillet J, Delunel R. 2013. Deciphering the driving forces of erosion rates on millennial to million-year timescales in glacially impacted landscapes: An example from the Western Alps. Journal of Geophysical Research: Earth Surface 118: 1491-1515. https://doi.org/10.1002/jgrf.20107.

Gölke M, Coblentz DD. 1996. Origins of the European regional stress field. Tectonophysics 266: 11-24.

Grasso JR, Guyoton F, Fréchet J, Gamond JF. 1992. Triggered earthquakes as stress gauge: Implication for the uppercrust behavior in the Grenoble area, France. Pure and Applied Geophysics 139: 579-605.

Grellet B, Combes P, Granier T, Philip H. 1993. Sismotectonique de la France métropolitaine dans son cadre géologique et géophysique. Société Géologique France. Mémoires de la société géologique de France 164: 76.

Grollimund B, Zoback MD. 2001. Did deglaciation trigger intraplate seismicity in the New Madrid seismic zone? Geology 29: 175-178.

Guéguen Y, Deffontaines B, Fruneau B, Heib MA, Michele M de, Raucoules D, et al. 2009. Monitoring residual mining subsidence of Nord Pas-de-Calais coal basin from differential and Persistent Scatterer Interferometry (Northern France). Journal of Applied Geophysics 69: 24-34. https://doi.org/10.1016/j.japp geo.2009.02.008.
Gueydan F, Leroy YM, Jolivet L, Agard P. 2003. Analysis of continental midcrustal strain localization induced by reactionsoftening and microfracturing. Journal of Geophysical Research: Solid Earth 108: 2064. https://doi.org/10.1029/2001JB000611.

Hays JD, Imbrie J, Shackleton NJ. 1976. Variations in the earth's orbit: Pacemaker of the ice ages. Science 194: 1121-1132.

Heidbach O, Reinecker J, Tingay M, Müller B, Sperner B, Fuchs K, et al. 2007. Plate boundary forces are not enough: Second- and third-order stress patterns highlighted in the World Stress Map database. Tectonics 26: TC6014. https://doi.org/10.1029/ 2007 TC002133.

Heidbach O, Rajabi M, Cui X, Fuchs K, Müller B, Reinecker J, et al. 2018. The World Stress Map database release 2016: Crustal stress pattern across scales. Tectonophysics 744: 484-498. https://doi.org/ 10.1016/j.tecto.2018.07.007.

Heimlich C, Gourmelen N, Masson F, Schmittbuhl J, Kim SW, Azzola J. 2015. Uplift around the geothermal power plant of Landau (Germany) as observed by In: SAR monitoring. Geothermal Energy 3: 1-12. https://doi.org/10.1186/s40517-014-0024-y.

Henrion E, Ulrich P, Masson F. 2015. Champ de vitesse GPS du NordEst de la France, apport des stations permanentes pour une précision submillimétrique. XYZ 142: 19-23.

Hinzen K-G. 2003. Stress field in the Northern Rhine area, Central Europe, from earthquake fault plane solutions. Tectonophysics 377 325-356. https://doi.org/10.1016/j.tecto.2003.10.004.

Holdsworth RE. 2004. Weak fault- Rotten core. Science 303: 181-182.

Jiménez-Munt I, Garcia-Castellanos D, Negredo AM, Platt JP. 2005. Gravitational and tectonic forces controlling postcollisional deformation and the present-day stress field of the Alps: Constraints from numerical modeling. Tectonics 24: TC5009. https://doi.org/10.1029/2004TC001754.

Johnston AC. 1989. The Seismicity of "Stable Continental Interiors". In: Gregersen S, Basham PW, eds. Earthquakes at North-Atlantic Passive Margins: Neotectonics and Postglacial Rebound, NATO ASI Series. Dordrecht: Springer Netherlands, pp. 299-327.

Jomard H, Cushing EM, Palumbo L, Baize S, David C, Chartier T. 2017. Transposing an active fault database into a seismic hazard fault model for nuclear facilities - Part 1: Building a database of potentially active faults (BDFA) for metropolitan France. Natural Hazards and Earth System Sciences 17: 1573-1584. https://doi.org/ 10.5194/nhess-17-1573-2017.

Jouanne F, Ménard G, Jault D. 1994. Present-day deformation of the French northwestern Alps/southern Jura mountains: comparison between historical triangulations. Geophysical Journal International 119: 151-165.

Jouanne F, Ménard G, Darmendrail X. 1995. Present-day vertical displacements in the north-western Alps and southern Jura Mountains: Data from leveling comparisons. Tectonics 14: 606-616.

Lacan P, Ortuño M. 2012. Active Tectonics of the Pyrenees: A review. Journal of Iberian Geology 38. https://doi.org/10.5209/ rev JIGE.2012.v38.n1.39203.

Le Pichon X, Rangin C, Hamon Y, Loget N, Lin JY, Andreani L, et al. 2010. Geodynamics of the France Southeast Basin. Bulletin de la Société Géologique de France 181: 477-501.

Lee WHK, Meyers H, Shimazaki K, eds. 1988. Historical seismograms and earthquakes of the world. San Diego: Academic Press.

Lenôtre N, Thierry P, Blanchin R, Brochard G. 1999. Current vertical movement demonstrated by comparative levelling in Brittany (northwestern France). Tectonophysics 301: 333-344.

Limoge-Schraen C, Giry C, Desprez C, Ragueneau F. 2014. Toward a large-scale seismic assessment method for heritage building: 
vulnerability of masonry baroque churches. European Journal of Environmental and Civil Engineering 20: 680-710. https://doi.org/ 10.1080/19648189.2015.1061459.

Majer EL, Baria R, Stark M, Oates S, Bommer J, Smith B, et al. 2007. Induced seismicity associated with Enhanced Geothermal Systems. Geothermics 36: 185-222. https://doi.org/10.1016/j.geother mics.2007.03.003.

Manchuel K, Traversa P, Baumont D, Cara M, Nayman E, Durouchoux C. 2018. The French seismic CATalogue (FCAT17). Bulletin of Earthquake Engineering 16: 2227-2251. https:// doi.org/10.1007/s10518-017-0236-1.

Marin S, Avouac J-P, Nicolas M, Schlupp A. 2004. A Probabilistic Approach to Seismic Hazard in Metropolitan France. Bulletin of the Seismological Society of America 94: 2137-2163.

Martinod J, Jouanne F, Taverna J, Ménard G, Gamond JF, Darmendrail X, et al. 1996. Present-day deformation of the Dauphine Alpine and Subalpine massifs (SE France). Geophysical Journal International 127: 189-200.

Masson F, Knoepfler A, Mayer M, Ulrich P, Heck B. 2010. Upper bounds of deformation in the Upper Rhine Graben from GPS data-First results from GURN (GNSS Upper Rhine Graben Network). In: EGU General Assembly, 4516 p.

Masson C, Mazzotti S, Vernant P. 2019a. Precision of continuous GPS velocities from statistical analysis of synthetic time series. Solid Earth 10: 329-342. https://doi.org/10.5194/se-10-329-2019.

Masson C, Mazzotti S, Vernant P, Doerflinger E. 2019b. Extracting small deformation beyond individual station precision from dense GNSS networks in France and Western Europe. Solid Earth 10: 1905-1920. https://doi.org/10.5194/se-10-1905-2019.

Mayor J, Traversa P, Calvet M, Margerin L. 2018. Tomography of crustal seismic attenuation in Metropolitan France: Implications for seismicity analysis. Bulletin of Earthquake Engineering 16(6): 2195-2210.

Mazabraud Y, Béthoux N, Guilbert J, Bellier O. 2005. Evidence for short-scale stress field variations within intraplate central-western France. Geophysical Journal International 160: 161-178. https:// doi.org/10.2113/gssgfbull.S7-XXII.1.93.

Mazzotti S. 2007. Geodynamic models for earthquake studies in intraplate North America. In: Stein S, Mazzotti S, eds. Geological Society of America-Special Papers 425: 17-33. https://doi.org/ 10.1130/2007.2425(02).

Mazzotti S. 2018. Challenges of integrating geodetic and modelbased strain rates into seismic hazard calculations in regions of low distributed deformation. In: European Seismological Commission, Valeta, Malta, ESC2018-S22-744.

Mazzotti S, Gueydan F. 2018. Control of tectonic inheritance on continental intraplate strain rate and seismicity. Tectonophysics 746: 602-610. https://doi.org/10.1016/j.tecto.2017.12.014.

Mazzotti S, Aubagnac C, Bollinger L, Coca Oscanoa K, Delouis B, Do Paco D, et al. subm. FMHex20: A database of earthquake focal mechanisms in metropolitan France and conterminous Western Europe. Bull. Soc. Geol. France.

Mey J, Scherler D, Wickert AD, Egholm DL, Tesauro M, Schildgen TF, et al. 2016. Glacial isostatic uplift of the European Alps. Nature Communications 7: 1-9. https://doi.org/10.1038/ncomms13382.

Mikko H, Smith CA, Lund B, Ask MVS, Munier R. 2015. LiDARderived inventory of post-glacial fault scarps in Sweden. GFF 137: 334-338. https://doi.org/10.1080/11035897.2015.1036360.

Molliex S, Rabineau M, Leroux E, Bourlès D, Authemayou C, Aslanian D, et al. 2016. Multi-approach quantification of denudation rates in the Gulf of Lion source-to-sink system (SE France). Earth and Planetary Science Letters 444: 101-115. https://doi.org/10.1016/j.eps1.2016.03.043.
Müller B, Zoback ML, Fuchs K, Mastin L, Gregesen S, Pavoni N, et al. 1992. Regional patterns of tectonic stress in Europe. Journal of Geophysical Research: Solid Earth 97: 11783-11803.

Neres M, Neves MC, Custódio S, Palano M, Fernandes R, Matias L, et al. 2018. Gravitational Potential Energy in Iberia: A Driver of Active Deformation in High-Topography Regions. Journal of Geophysical Research 123: 10277-10296. https://doi.org/10.1029/ 2017JB015002.

Nguyen HN, Vernant P, Mazzotti S, Khazaradze G, Asensio E. 2016. 3-D GPS velocity field and its implications on the present-day postorogenic deformation of the Western Alps and Pyrenees. Solid Earth 7: 1349-1363. https://doi.org/10.5194/se-7-1349-2016.

Nicolas M, Santoire JP, Delpech PY. 1990. Intraplate seismicity: new seismotectonic data in Western Europe. Tectonophysics 179: 2753.

Nocquet J-M. 2012. Present-day kinematics of the Mediterranean: A comprehensive overview of GPS results. Tectonophysics 579: 220 242. https://doi.org/10.1016/j.tecto.2012.03.037.

Nocquet J-M, Calais E, Parsons B. 2005. Geodetic constraints on glacial isostatic adjustment in Europe. Geophysical Research Letters 32: 29077. https://doi.org/10.1029/2004GL022174.

Nocquet J-M, Sue C, Walpersdorf A, Tran T, Lenôtre N, Vernant P, et al. 2016. Present-day uplift of the western Alps. Scientific Reports 6. https://doi.org/10.1038/srep28404.

Olivetti V, Godard V, Bellier O. 2016. Cenozoic rejuvenation events of Massif Central topography (France): Insights from cosmogenic denudation rates and river profiles. Earth and Planetary Science Letters 444: 179-191. https://doi.org/10.1016/j.eps1.2016.03.049.

Palano M, González PJ, Fernández J. 2015. The Diffuse Plate boundary of Nubia and Iberia in the Western Mediterranean: Crustal deformation evidence for viscous coupling and fragmented lithosphere. Earth and Planetary Science Letters 430: 439-447. https://doi.org/10.1016/j.epsl.2015.08.040.

Patton H, Hubbard A, Andreassen K, Winsborrow M, Stroeven AP. 2016. The build-up, configuration, and dynamical sensitivity of the Eurasian ice-sheet complex to Late Weichselian climatic and oceanic forcing. Quaternary Science Reviews 153: 97-121. https:// doi.org/10.1016/j.quascirev.2016.10.009.

Peltier WR, Argus DF, Drummond R. 2015. Space geodesy constrains ice age terminal deglaciation: The global ICE-6G_C (VM5a) model. Journal of Geophysical Research: Solid Earth 120: 450 487. https://doi.org/10.1002/2014JB011176.

Pérez-Gussinyé M, Watts AB. 2005. The long-term strength of Europe and its implications for plate-forming processes. Nature 436: 381-384. https://doi.org/10.1038/nature03854.

Perrey A. 1845. Mémoire sur les tremblements de terre ressentis en France, en Belgique et en Hollande, depuis le quatrième siècle de l'ère chrétienne jusqu'à nos jours (1843 inclusiv.). Bruxelles: M. Hayez.

Poursoulis G, Levret-Albaret A. 2014. Le tremblement de terre de 1708 à Manosque. Apport d'une étude historique et archéologique à l'évaluation du risque sismique en Moyenne Durance. Perpignan, France.

Précigout J, Gueydan F. 2009. Mantle weakening and strain localization: Implications for the long-term strength of the continental lithosphere. Geology 37: 147-150. https://doi.org/ 10.1130/G25239A.1.

Provost L, Scotti O. 2020. QUake-MD: Open-Source Code to Quantify Uncertainties in Magnitude-Depth Estimates of Earthquakes from Macroseismic Intensities. Seismological Research Letters. https://doi.org/10.1785/0220200064.

QGIS Development Team. 2019. QGIS Geographic Information System. Open Source Geospatial Foundation. 
Quenet G, Baumont D, Scotti O, Levret A. 2004. The 14 August 1708 Manosque, France earthquake: new constraints on the damage area from in-depth historical studies. Annals of Geophysics 47: 583-595.

R Core Team. 2019. R: A Language and Environment for Statistical Computing. Vienna, Austria: $\mathrm{R}$ Foundation for Statistical Computing.

Reilly WI, Gubler E. 1990. Crustal strain in Switzerland 1870-1970. Geophysical Journal International 103: 251-256.

Rigo A, Cushing EM. 1999. Effets topographiques sur les comparaisons de profils de nivellement: cas français de SaintPaul-de-Fenouillet (Pyrénées-Orientales) et d'Arudy (PyrénéesAtlantiques). C. R. Acad. Sci. 329: 697-704.

Rigo A, Vernant P, Feigl K, Goula X, Khazaradze G, Talaya J, et al. 2015. Present-day deformation of the Pyrenees revealed by GPS surveying and earthquake focal mechanisms until 2011. Geophysical Journal International 201: 947-964. https://doi.org/10.1093/ gji/ggv052.

Sánchez L, Völksen C, Sokolov A, Arenz H, Seitz F. 2018. Presentday surface deformation of the Alpine Region inferred from geodetic techniques. Earth System Science Data 10: 1503-1526. https://doi.org/10.5194/essd-10-1503-2018.

Santamaría-Gómez A, Bouin M-N, Collilieux X, Wöppelmann G. 2011. Correlated errors in GPS position time series: Implications for velocity estimates. Journal of Geophysical Research: Solid Earth 116: B01405. https://doi.org/10.1029/2010JB007701.

Schaller M, von Blanckenburg F, Hovius N, Kubik P. 2001. Largescale erosion rates from in situ-produced cosmogenic nuclides in European river sediments. Earth and Planetary Science Letters 188: 441-458.

Schulte SM, Mooney WD. 2005. An updated global earthquake catalogue for stable continental regions: reassessing the correlation with ancient rifts. Geophysical Journal International 161: 707721. https://doi.org/10.1111/j.1365-246X.2005.02554.x.

Scotti O, Baumont D, Quenet G, Levret A. 2004. The French macroseismic database SISFRANCE: objectives, results and perspectives. Annals of Geophysics 47: 571-581.

Sébrier M, Ghafiri A, Bles J-L. 1997. Paleoseismicity in France: Fault trench studies in a region of moderate seismicity. Journal of Geodynamics 24: 207-217. https://doi.org/10.1016/S0264-3707 (97)00005-7.

Selverstone J. 2005. Are the Alps Collapsing. Annual Review of Earth and Planetary Sciences 33: 113-132. https://doi.org/10.1146/ annurev.earth.33.092203.122535.

Serpelloni E, Faccenna C, Spada G, Dong D, Williams SDP. 2013. Vertical GPS ground motion rates in the Euro-Mediterranean region: New evidence of velocity gradients at different spatial scales along the Nubia-Eurasia plate boundary. Journal of Geophysical Research: Solid Earth 118: 6003-6024. https://doi. org/10.1002/2013JB010102.

Souriau A, Rigo A, Sylvander M, Benahmed S, Grimaud F. 2014. Seismicity in central-western Pyrenees (France): A consequence of the subsidence of dense exhumed bodies. Tectonophysics 621: 123131. https://doi.org/10.1016/j.tecto.2014.02.008.

Steer P, Simoes M, Cattin R, Shyu JBH. 2014. Erosion influences the seismicity of active thrust faults. Nature Communications 5: 5564. https://doi.org/10.1038/ncomms6564.

Steer P, Jeandet L, Cubas N, Marc O, Meunier P, Hovius N, et al. 2017. Typhoon-driven landsliding induces earthquakes: example of the 2009 Morakot typhoon. Vienna, Austria: EGU2017-9089.

Steffen R, Steffen H, Wu P, Eaton DW. 2014. Stress and fault parameters affecting fault slip magnitude and activation time during a glacial cycle. Tectonics 33: 1461-1476. https://doi.org/ 10.1002/2013TC003450.
Stein S, Mazzotti S, eds. 2007. Continental intraplate earthquakes: Science, hazard, and policy issues. Boulder, CO: Geological Society of America.

Stocchi P, Spada G, Cianetti S. 2005. Isostatic rebound following the Alpine deglaciation: impact on the sea level variations and vertical movements in the Mediterranean region. Geophysical Journal International 162: 137-147. https://doi.org/10.1111/ j.1365-246X.2005.02653.x.

Strasser M, Anselmetti FS, Fäh D, Giardini D, Schnellmann M. 2006. Magnitudes and source areas of large prehistoric northern Alpine earthquakes revealed by slope failures in lakes. Geology 34: 1005. https://doi.org/10.1130/G22784A.1.

Sue C, Thouvenot F, Fréchet J, Tricart P. 1999. Widespread extension in the core of the western Alps revealed by earthquake analysis. Journal of Geophysical Research: Solid Earth 104: 25611-25622.

Sue C, Delacou B, Champagnac J-D, Allanic C, Burkhard M. 2007. Aseismic deformation in the Alps: GPS vs. seismic strain quantification. Terra Nova 19: 182-188. https://doi.org/10.1111/ j.1365-3121.2007.00732.x.

Sykes LR. 1978. Intraplate seismicity, reactivation of preexisting zones of weakness, alkaline magmatism, and other tectonism postdating continental fragmentation. Review of Geophysics 16: 621. https://doi.org/10.1029/RG016i004p00621.

Talwani P. 2016. On the nature of intraplate earthquakes. Journal of Seismology 1-22. https://doi.org/10.1007/s10950-016-9582-8.

Tarayoun A, Mazzotti S, Craymer MR, Henton JA. 2018. Structural Inheritance Control on Intraplate Present-Day Deformation: GPS Strain Rate Variations in the Saint Lawrence Valley, Eastern Canada. Journal of Geophysical Research 123: 7004-7020. https:// doi.org/10.1029/2017JB015417.

Tarayoun A, Mazzotti S, Gueydan F. 2019. Quantitative impact of structural inheritance on present-day deformation and seismicity concentration in intraplate deformation zones. Earth and Planetary Science Letters 518: 160-171. https://doi.org/10.1016/j. eps1.2019.04.043.

Terrier M, Bertil D, Rohmer J. 2018. Méthode d'identification des failles actives en domaine de déformation lente. Rapport final. BRGM/RP-68553-FR, 87 p.

Tesauro M, Kaban MK, Cloetingh SAPL. 2009. How rigid is Europe's lithosphere? Geophysical Research Letters 36. https://doi.org/ 10.1029/2009GL039229.

The RENAG Team. 2010. RESIF-RENAG: The French GPS component of a European infrastructure. In: $E G U$ General Assembly, Vienna, Austria.

Tommasi A, Knoll M, Vauchez A, Signorelli JW, Thoraval C, Logé R. 2009. Structural reactivation in plate tectonics controlled by olivine crystal anisotropy. Nature Geoscience 2: 423-427. https://doi.org/ 10.1038/ngeo528.

van Camp M, de Viron O, Scherneck H-G, Hinzen K-G, Williams SDP, Lecocq T, et al. 2011. Repeated absolute gravity measurements for monitoring slow intraplate vertical deformation in western Europe. Journal of Geophysical Research: Solid Earth 116: B08402. https://doi.org/10.1029/2010JB008174.

Vernant P, Hivert F, Chéry J, Steer P, Cattin R, Rigo A. 2013. Erosioninduced isostatic rebound triggers extension in low convergent mountain ranges. Geology 41: 467-470. https://doi.org/10.1130/ G33942.1.

Vigny C, Chéry J, Duquesnoy T, Jouanne F, Ammann J, Anzidei M, et al. 2002. GPS network monitors the Western Alps' deformation over a five-year period: 1993-1998. Journal of Geodesy 76: 63-76. https://doi.org/10.1007/s00190-001-0231-8.

Volant P, Levret A, Carbon D, Scotti O, Combescure D, Verdel T, et al. 2008. An archaeo-seismological study of the Nîmes Roman 
aqueduct, France: indirect evidence for an $\mathrm{M}>6$ seismic event? Natural Hazards 49: 53-77. https://doi.org/10.1007/ s11069-008-9276-9.

Vrolijk P, Pevear D, Covey M, LaRiviere A. 2018. Fault gouge dating: history and evolution. Peter Vrolijk et al. Fault gouge dating. Clay Minerals 53: 305-324. https://doi.org/10.1180/clm.2018.22.

Walpersdorf A, Sue C, Baize S, Cotte N, Bascou P, Beauval C, et al. 2015. Coherence between geodetic and seismic deformation in a context of slow tectonic activity (SW Alps, France). Journal of Geodynamics 85: 58-65. https://doi.org/10.1016/j. jog.2015.02.001.

Walpersdorf A, Pinget L, Vernant P, Sue C, Deprez A, The RENAG Team. 2018. Does Long-Term GPS in the Western Alps Finally Confirm Earthquake Mechanisms? Tectonics 91: 937. https://doi. org/10.1029/96JB03860.

Wang Z, Cobb JC. 2012. A critique of probabilistic versus deterministic seismic hazard analysis with special reference to the New Madrid seismic zone. In: Recent Advances in North American Paleoseismology and Neotectonics East of the Rockies. Geological Society of America Special Paper, pp. 259-275.

Wells DL, Coppersmith KJ. 1994. New empirical relationships among magnitude, rupture length, rupture width, rupture area, and surface displacement. Bulletin of the Seismological Society of America 84: 974-1002.

Wessel P, Smith WHF, Scharroo R, Luis J, Wobbe F. 2013. Generic Mapping Tools: Improved Version Released. Eos, Transactions American Geophysical Union 94: 409-410. https://doi.org/ 10.1002/2013EO450001.

Willett SD, Schlunegger F, Picotti V. 2006. Messinian climate change and erosional destruction of the central European Alps. Geology 34: 613. https://doi.org/10.1130/G22280.1.

Williams SDP. 2003. The effect of coloured noise on the uncertainties of rates estimated from geodetic time series. Journal of Geodesy 76: 483-494. https://doi.org/10.1007/s00190-002-0283-4.

Wu P, Mazzotti S. 2007. Effects of a lithospheric weak zone on postglacial seismotectonics in eastern Canada and the northeastern United States (S. Stein, S. Mazzotti, eds.). Geological Society of America-Special Papers 425: 113-128. https://doi.org/10.1130/ 2007.2425(09).

Zoback ML. 1992. First- and second-order patterns of stress in the lithosphere: The World Stress Map project. Journal of Geophysical Research: Solid Earth 97: 11703-11728.

Zoback ML, Zoback MD, Adams J, Assumpção M, Bell S, Bergman EA, et al. 1989. Global patterns of tectonic stress. Nature 341: 291-298.

Cite this article as: Mazzotti S, Jomard H, Masson F. 2020. Processes and deformation rates generating seismicity in metropolitan France and conterminous Western Europe, BSGF - Earth Sciences Bulletin 191: 19. 